Article

\title{
Comfort within Budget: Assessing the Cost-Effectiveness of Envelope Improvements in Single-Family Affordable Housing
}

\author{
Renata Tubelo $^{1, *(\mathbb{D}}$, Lucelia Rodrigues ${ }^{2}$, , Mark Gillott $^{2}\left(\mathbb{D}\right.$ and May Zune ${ }^{3}$ \\ 1 Buildings, Energy and Environment Research Group, Faculty of Engineering, University of Nottingham, \\ Nottingham NG7 2RD, UK \\ 2 Department of Architecture and Built Environment, Faculty of Engineering, University of Nottingham, \\ Nottingham NG7 2RD, UK; lucelia.rodrigues@nottingham.ac.uk (L.R.); mark.gillott@nottingham.ac.uk (M.G.) \\ 3 Azura BIM Solutions (Yangon) and Shwe Eain Construction (Bhamo), Hlaing 11051, Myanmar; \\ mayzune.uon@gmail.com \\ * Correspondence: renata.tubelo@nottingham.ac.uk; Tel.: +44-01159513167
}

Citation: Tubelo, R.; Rodrigues, L.; Gillott, M.; Zune, M. Comfort within Budget: Assessing the

Cost-Effectiveness of Envelope Improvements in Single-Family Affordable Housing. Sustainability 2021, 13, 3054. https://doi.org/ $10.3390 /$ su13063054

Academic Editor: Giuseppe Margani

Received: 29 January 2021

Accepted: 2 March 2021

Published: 11 March 2021

Publisher's Note: MDPI stays neutral with regard to jurisdictional claims in published maps and institutional affiliations.

Copyright: (C) 2021 by the authors. Licensee MDPI, Basel, Switzerland. This article is an open access article distributed under the terms and conditions of the Creative Commons Attribution (CC BY) license (https:/ / creativecommons.org/licenses/by/ $4.0 /)$.

\begin{abstract}
In Brazil, the delivery of homes for low-inc ome households is dictated by costs rather than performance. Issues such as the impact of climate change, affordability of operational energy use, and lack of energy security are not taken into account, even though they can severely impact the occupants. In this work, the authors evaluated the thermal performance of two affordable houses as-built and after the integration of envelope improvements. A new replicable method to evaluate the cost-effectiveness of these improvements was proposed. The case study houses comprise the most common affordable housing type delivered widely across Brazil and a proposition of a better affordable housing solution, built in Porto Alegre, southern Brazil, integrating passive design strategies to increase thermal comfort. The findings reveal a potential for improving indoor thermal conditions by up to $76 \%$ and $73 \%$, respectively, if costs are not a concern, and $40 \%$ and $45 \%$ with a cost increase of $12 \%$ and $9 \%$ if a comfort criterion of $20-25^{\circ} \mathrm{C}$ was considered. Equations to estimate costs of improvements in affordable housing were developed. The authors concluded that there is a great scope for building envelope optimisation, and that this is still possible without significant impact on budget.
\end{abstract}

Keywords: sustainable and affordable architecture; affordable housing; social housing; optimised building envelope; thermal comfort; thermal performance; costs; cost-effectiveness; case study

\section{Introduction}

In 2009, the Brazilian government launched a social housing programme, Minha Casa, Minha Vida (MCMV), My House, My Life in English, to help the provision and financing of homes for the most economically and socially disadvantaged classes. Within a decade, the programme delivered 4 million new housing units [1], equivalent to nearly $7 \%$ of the 2010 country's existing housing stock of 57.3 million units [2].

The majority of the social housing in Brazil, delivered through this and previous programmes, consists of a one-storey two-bedroom detached house, the typology adopted in this study. The design of these homes does not consider the country's varied climate (8 climates zones) and has seen no improvements for decades [3]. The advancing consequences of global warming and climate change have also not been considered. Not unexpectedly, these homes have been associated with poor thermal performance [4].

The poor thermal performance is also resulting in the need for heating and cooling in many areas. This exposes the poorer households at risk of being unable to afford their energy bills. The Brazilian electrical energy matrix has increased the contribution of thermoelectric power to supplement the country's ever-increasing energy demand [5,6], increasing residential energy prices [7]. The demand for electricity for air conditioners in the residential sector more than tripled in a decade, and it is estimated to increase $5.4 \%$ per 
year until 2035 [8], or even more if the equipment acquisition becomes within economic reach of more households [8,9].

In the face of millions of poor people, it is essential that social housing is able to deliver thermal comfort for the duration of the building's lifecycle and take into consideration financial limitations by avoiding an increase in operational energy use [4]. The current focus on houses' upfront costs rather than on comfort and operational cost $[4,10]$ has to be shifted.

Studies have suggested ways to improve the levels of thermal performance delivered in the Brazilian affordable housing in order to meet current and future demands $[4,7,10]$. Some suggest that there is a potential for energy demand reduction of $20 \%$ through the adoption of improved building envelopes with the use of insulation and controlled internal air flow [11]. Studies using computer future predictions support that optimisation of the building envelopes, predominantly walls and roof, would be able to improve the building thermal performance through the use of low thermal transmittance walls combined with insulated roofs of lower solar absorptance [10]. Combined strategies such as improving more than one of the building envelope components and the integration of natural ventilation presented even better results [10].

The question whether these proposed solutions are affordable remains and is therefore the focus of this paper. In order to take into account the environmental impact of this housing typology as well as the needs of the most economically and socially disadvantaged classes, this paper look at the performance and costs associated with the construction and running of two typical affordable Brazilian single-family homes with the aim of identifying design aspects that can be optimised within budget. This is the first known work that is able to add a cost to the comfort benefits of envelope improvement and suggest a method that can be used widely in cost-performance optimisation of affordable homes.

\section{Porto Alegre's Climate}

Porto Alegre is located at latitude $30.05^{\circ} \mathrm{S}$ and altitude $47 \mathrm{~m}$, classified within the Brazilian climate zone 3 [12]. The city has a humid subtropical climate with seasonal and daily variation (Cfa according to Köppen climatic classification) with annual average temperature of $18-20^{\circ} \mathrm{C}$ [13]. Summers are warm to hot as well as humid, and winters are cold of medium to high amplitude [14,15] (Figures 1 and 2). Cold winter winds mostly come from southerly and southeasterly direction and cool summer winds mostly come from easterly direction. Monthly direct solar radiation is significant throughout the year, with lower distribution from May to August. Monthly diffuse solar radiation is significant, meaning that shade is not effective in overcast warm days, because all façades tend to receive the same amount of heat gains $[16,17]$, which would require adequate design building envelope to reduce the solar heat gain transferred by convection. 



Figure 1. Temperature, relative humidity, heating and cooling demands of Porto Alegre, based on Roriz [18] dataset.



Figure 2. Frequency of the temperatures per year and seasons in Porto Alegre, based on Roriz [18] dataset.

It has been estimated that Brazil has warmed by about $0.7^{\circ} \mathrm{C}$ over the last 50 years, which is slightly higher than the best estimate of the global average increase of $0.64{ }^{\circ} \mathrm{C}[19,20]$. For a global scale, the IPCC projects that the increase in mean surface temperature by the end of the twenty-first century (2081-2100) relative to $1986-2005$ is likely to be $0.3{ }^{\circ} \mathrm{C}$ to $1.7^{\circ} \mathrm{C}$ under the RCP2.6 scenario (best case scenario, very low future concentrations of greenhouse gases), and $2.6^{\circ} \mathrm{C}$ to $4.8^{\circ} \mathrm{C}$ under the RCP8.5 scenario (worst case scenario, very high future concentrations of greenhouse gases) [21]. For a regional scale, a significant climate shift in Brazil can be observed and project climate shifts 1901-2100 depicted by the world maps of the Koppen climate classification. In particular, obvious differences between the prediction scenarios A1F1 for 2001-2025 and 2075-2100 shows an expansion of equatorial climate area and a significant loss in a warm temperate area (Figure 3), an indication of increased temperatures in future climate scenarios of Porto Alegre [22,23]. During 2001-2010, the typical weather year data showed that only $0.06 \%$ of annual hours were above dry-bulb temperature $37^{\circ} \mathrm{C}$. If hourly temperature increments of $1{ }^{\circ} \mathrm{C}, 2^{\circ} \mathrm{C}$, $3{ }^{\circ} \mathrm{C}$, and $4{ }^{\circ} \mathrm{C}$ were considered using a typical weather year data, annual hours above dry-bulb temperature could increase to $0.2 \%, 0.4 \%, 0.7 \%$, and $1.2 \%$, respectively. As a result, the cooling and heating degree-hours for Porto Alegre's climate would be changed 
(Figure 3), as well as annual hours for extremely high temperatures above $37{ }^{\circ} \mathrm{C}$ would be increased. This is a rough calculation; therefore, the actual $24 \mathrm{~h}$ temperature profiles could be different; however, above the air temperature $37^{\circ} \mathrm{C}$ with a relative humidity of $40 \%$ in shaded areas, a heat-index temperature is increased, then human health is threatened with increased risk of heat cramps, heat exhaustion, and heat stroke [24].

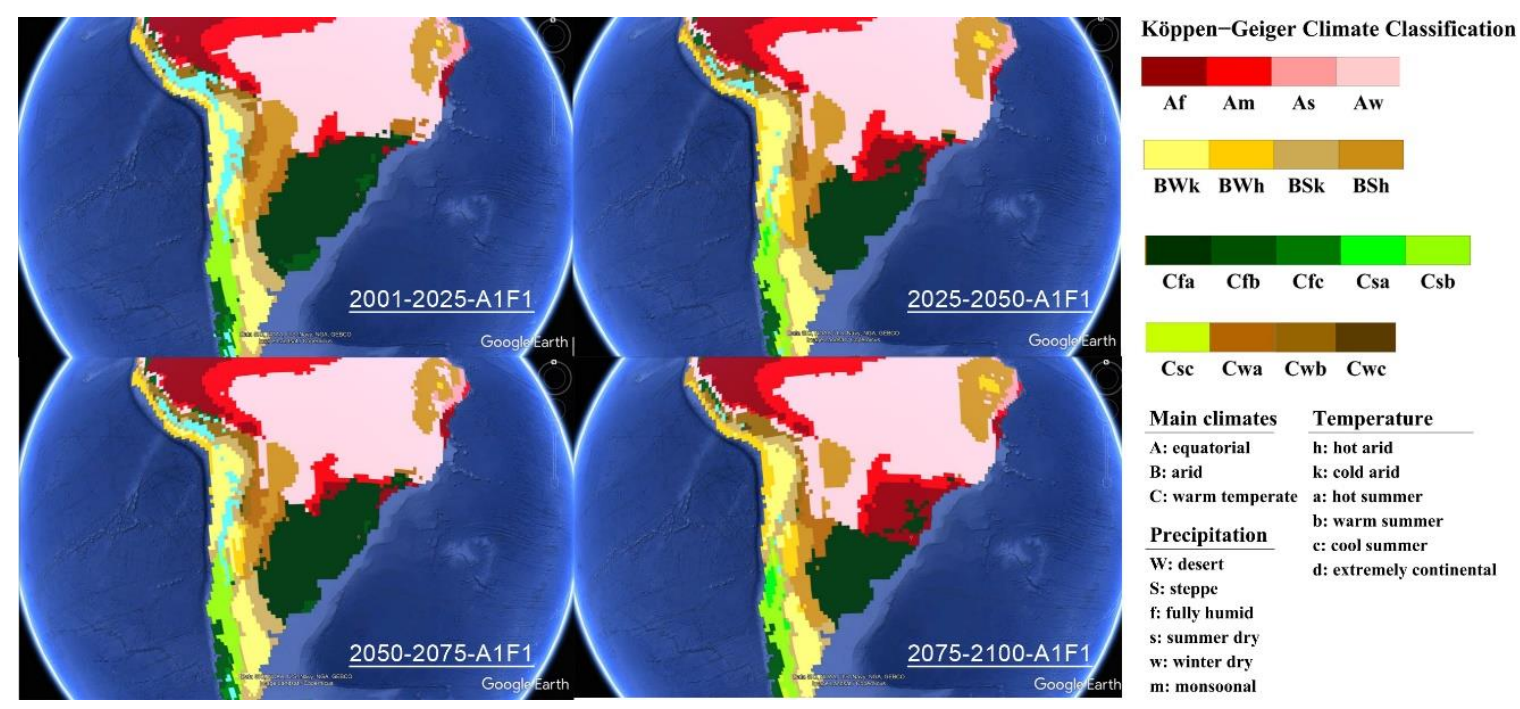

Figure 3. Observed and project climate shifts 1901-2100 depicted by the world maps of the Köppen climate classification for Brazil, created by the authors using A1F1 scenario by IPCC, obtained from Rubel and Kottek [22,23].

In Brazil, a building's life span is equivalent to 50 years, established by the Brazilian standards NBR 15575 [25]; hence, to respond to future climate change scenarios, it is essential to consider energy efficiency adaptation, especially for the neediest households [10].

This study looks at improving indoor thermal comfort, while aiming to tackle extremes of high and low temperatures, by cost-effectively optimising the building envelope.

\section{Envelope Optimisation}

Design guidelines for climate mitigation recommend the use of cross ventilation and solar shading in summer as well as direct solar heat gain and heavy internal walls in winter [12]. Opaque envelope should have U-values of up to 3.7 or $2.5 \mathrm{~W} / \mathrm{m}^{2} \mathrm{~K}$ for walls depending on the absorptance values $(\leq 0.6$ or $>0.6)$ and of up to 2.3 and $1.5 \mathrm{~W} / \mathrm{m}^{2} \mathrm{~K}$ for roofs also related to absorptance values [26,27], respectively. Transparent elements should have areas between $15 \%$ and $25 \%$ of the floor area [12].

However, the continued underperformance reported in these affordable residential buildings $[3,4,10,28,29]$, where their envelopes are inappropriate and have high transmittance values, urge a review of these envelopes in order to achieve better comfort level for present and in views of future climate scenarios.

The Passivhaus standard is a fabric-first approach that achieves high levels of indoor thermal comfort with extremely low heating and cooling loads [30]. The Passivhaus standard holistically incorporates five basic principles [31]: superinsulation, thermal bridge free construction, airtight building envelope, high-performance specifications for windows and doors, and mechanical ventilation with a heat recovery system (MVHR). Despite its original concepts, the main delivery of the standard is a robust and insulated building envelope with low thermal transmittance values. It was originally designed for cold climates, but a consolidated body of research has already investigated its suitability and applicability in temperate and warm climates [30,32]. However, even highly insulated and airtight Passivhaus buildings with active ventilation can face a summer overheating risk [33]. Therefore, optimisation of several design inputs for Passivhaus buildings, including external shading devices, thermal mass effect and glazing ratios are becoming 
increasingly relevant to prevent summer overheating even in mild climates [34]. For the studied climate, which has a great solar heating potential in winter, it can also impact on overheating in summer; therefore, careful consideration of insulation levels as well as ventilation to prevent extreme temperatures, in addition to solar shading for passive cooling.

The U-values for the opaque envelope in the central European Passivhaus is a range from 0.10 to $0.15 \mathrm{~W} / \mathrm{m}^{2} \mathrm{~K}$ and these values may be slightly higher or lower depending on the climate and also the exposed areas of the envelope [35]. Passivhaus buildings in warmer climates are mostly built with slightly higher U-values than in cold climates and have additional design features (e.g., ventilation, shading) to meet the local contexts differently [36-39].

\section{Case Studies}

Two case studies were investigated: a generic representative model of the 1-storey 2-bedroom detached MCMV housing typology; and the Alvorada House, designed and built based on the typically affordable housing typology but also integrating a range of passive design strategies and sustainable principles to increase its thermal comfort levels.

The rationale for the choice was because MCMV house is a representation of one of the most common housing typologies since and beyond the launch of the housing programme in 2009 and the Alvorada House was supposed to be a step up on the design of affordable houses. The latter was designed and built for the climate of Porto Alegre, southern Brazil, using passive design strategies as well as traditional techniques, which gives the building character and climate suitability, not often found in buildings of this kind.

Due to the scope of this work, all the analyses were done considering the climate of Porto Alegre for both houses. A larger study considering other Brazilian climates can be found elsewhere [29].

\subsection{The MCMV House}

The MCMV is one of the typical housing typologies adopted under the umbrella of the Brazilian housing programme. Developed most in the outskirts of the cities, in a large and repetitive pattern, this typology is composed of two bedrooms, an integrated kitchen and living room, bathroom and an external area used for laundry (Figure 4).

With an internal space of just over 36 square metres, it was designed to meet the very basic needs of a small family. The design of the house can be flexible as long it complies with the minimum construction requirements, minimum furniture provision and minimum total internal area set out by the Ministério das Cidades [40]. Even though it does not need to have a fixed design, the resultant design is usually of similar typology of rectangular shape and pitched roof that gives the houses a monotonous and standardised aspect [7] (see Figure 4). Materials and performance are not determined by the government or differences in culture and climate.

The predominant features of this house include internal and external walls of $13 \mathrm{~cm}$ made of hollow ceramic brick or concrete block, both with external render and internal plaster [4], although there is a great variability of the construction component. The present investigation presupposed a building envelope that complies with the requirements of the Brazilian standard NBR $15575[26,27]$ as a starting point. The houses were considered with $14 \mathrm{~cm}$ layer of load-bearing hollow brick with a layer of external render and internal plaster $\left(2.78 \mathrm{~W} / \mathrm{m}^{2} \mathrm{~K}<3.7 \mathrm{~W} / \mathrm{m}^{2} \mathrm{~K}\right.$ standard requirement for absorptance $\left.\leq 0.6\right)$, shown in Figure 4 . Roof made out of clay roof tiles with aluminium foil layer between the structures to reduce downward heat flow, finished internally with timber ceiling $\left(0.92 \mathrm{~W} / \mathrm{m}^{2} \mathrm{~K}<\right.$ $1.5 \mathrm{~W} / \mathrm{m}^{2} \mathrm{~K}$ standard requirement for absorptance $>0.6$ ). Windows were considered made out of aluminium with a $3 \mathrm{~mm}$ single glass (U-value: $5.78 \mathrm{~W} / \mathrm{m}^{2} \mathrm{~K}$ ). 


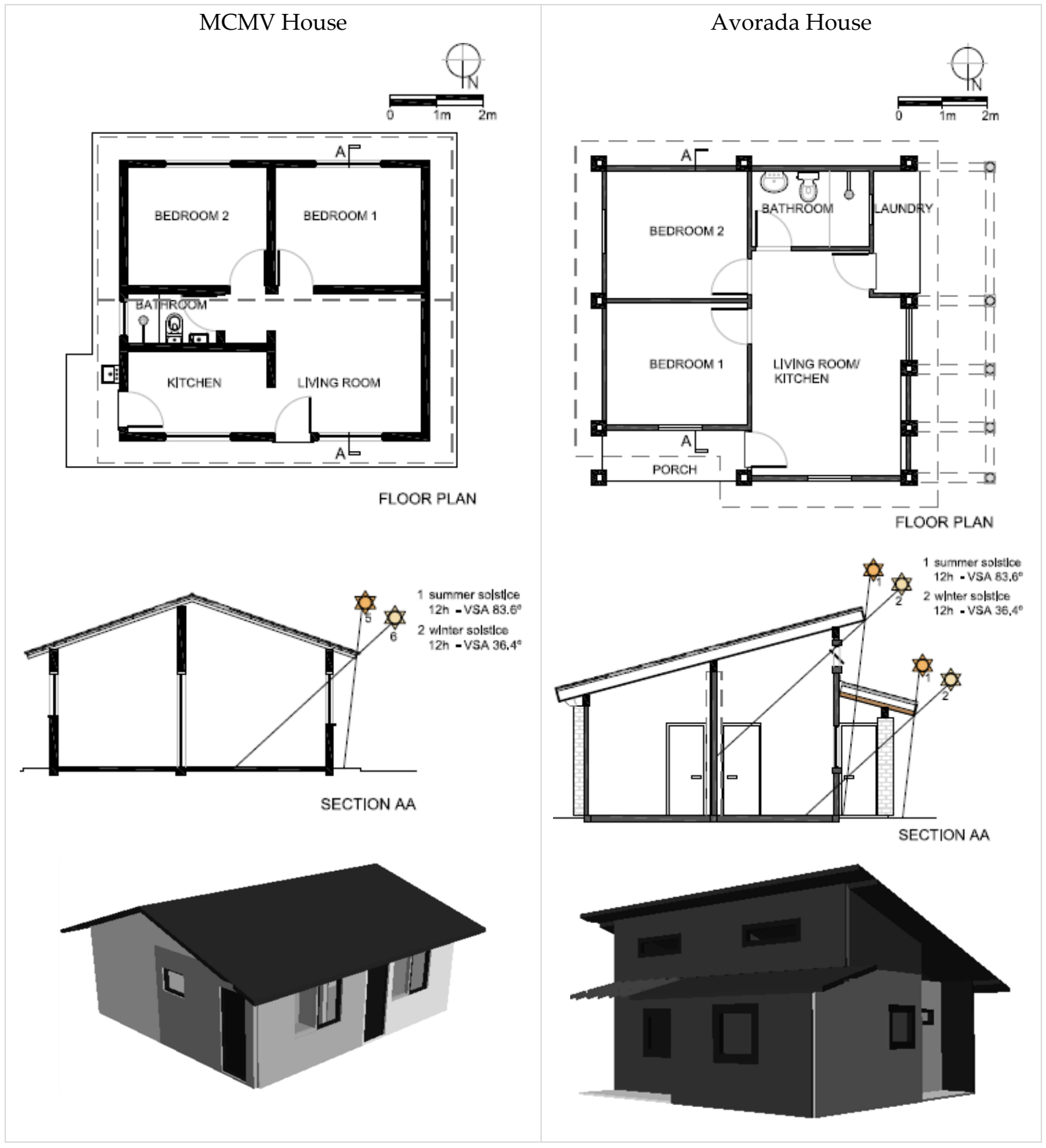

Figure 4. Case studies-Floor plans, sections and 3D models.

There are no recommendations in terms of passive design strategies, except by the use of eaves of minimum length of $50 \mathrm{~cm}$ [40]. Its use may be beneficial as a shading device when appropriately oriented as well as combined with windows adequately placed at specific height. However, there is neither association to those variables on the recommendations nor adjustment in terms of the length of the eaves according to the location of the building.

For this investigation, the design was optimised by maximising windows in the north façade (54\%) according to the standard dimensions available in the market and local building codes. These were placed at typical heights and additional north shading device was integrated to cut-off direct radiation from the equinoxes through the summer period as per identified in the climate analysis. 


\subsection{The Alvorada House}

The Alvorada House was designed as part of a process of developing more sustainable benchmarks for the production of affordable housing [41]. The house was conceived and built by the Universidade Federal do Rio Grande do Sul (UFRGS), 'Federal University of Rio Grande do Sul' in English, through the Núcleo Orientado para a Inovação da Edificação (NORIE), 'Hub for Innovation of Buildings' in English, involving staff and postgraduate students with architectural and engineering backgrounds. It was designed as a prototype for experimental and demonstration purposes of more energy efficient and thermally comfortable affordable housing [41]. The construction of the house took place between 2001 and 2003 [41].

The Alvorada House comprises the long-established use of rectangular plan and pitched roof typically employed in houses for the neediest householders, combined with a set of passive design strategies articulated to regional and commonly used materials (e.g., solid ceramic brick). Its design incorporated important changes on the building shape related to its original typology: the house was designed using sheltered external areas-porches-giving the building a transition space between private and public, being at the same time used to shade the windows and ensure the delivery of better levels of indoor thermal comfort. Its internal area, however, does not differ greatly from the typical MCMV typology, just over 38 square metres (Table 1). However, its floor-to-ceiling height aimed to promote a sense of bigger spaces in comparison to the typical typology, as well as aid Buildings, Energy and Environment Research Grouping performance.

The house was designed prior to the Brazilian standard NBR15575 [25-27] and for this reason it does not comply fully with the requirements established by the standard in terms of the thermal transmittance values (Table 1). Alvorada's construction components and design strategies were described in Sattler [41]. The walls were predominately made of $11 \mathrm{~cm}$ of solid bricks $\left(3.57 \mathrm{~W} / \mathrm{m}^{2} \mathrm{~K}\right)$, with an additional external layer of mortar on the west façade $\left(3.46 \mathrm{~W} / \mathrm{m}^{2} \mathrm{~K}\right)$ and an external and internal layer of mortar on the south façade $\left(3.36 \mathrm{~W} / \mathrm{m}^{2} \mathrm{~K}\right)$ for higher thermal transmittance due to their exposure to the solar gains and cold winds, respectively. The west façade had also some parts built of 2-layer solid brick with an external layer of mortar $\left(1.82 \mathrm{~W} / \mathrm{m}^{2} \mathrm{~K}\right)$. Roof was built using roman clay roof tiles with aluminium foil layer between the structures to reduce downward heat flow, finished internally with a cedar lumber ceiling $\left(0.98 \mathrm{~W} / \mathrm{m}^{2} \mathrm{~K}\right)$. Windows were made out of timber frame and $3 \mathrm{~mm}$ single glazing with a high percentage of frame $\left(5.78 \mathrm{~W} / \mathrm{m}^{2} \mathrm{~K}\right)$.

The Alvorada House passive design strategies consisted of the appropriate position of the fenestrations, ventilation, and shading strategies. Windows were placed predominantly facing north $(58.5 \%)$, at different levels to allow stack ventilation. No fenestrations were considered facing south to decrease heat losses in winter; the remaining windows were considered facing east and west, allowing cross ventilation in summer (prevailing direction of cool summer winds). Shading was ensured in the summertime through the approximately $60 \mathrm{~cm}$ eave on the north façade (Figure 5), and through foldable shutters on the east façade. On the west façade, the fenestration was supposed to be covered up by an external structure with deciduous vegetation but in itself was not successfully able to deliver the intended shading, and thus, not considered in this analysis (decreasing its potential performance). Roof was designed to be ventilated in summer. Its ventilation system comprised two apertures in the north and south façades that should be kept opened in summer to force the fresh air to pass through the roof structure. It was kept closed for simulation and comparison purposes. 
Table 1. Case studies-Building envelope main components.

\section{House}

External/Internal walls

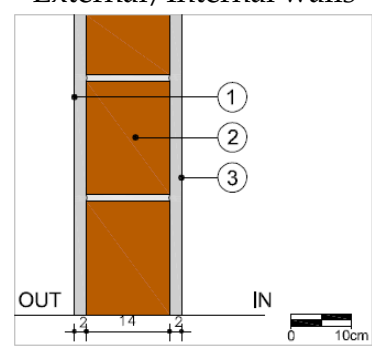

Hollow ceramic block wall, lime cement render and plaster, $180 \mathrm{~mm}, 2.78 \mathrm{~W} / \mathrm{m}^{2} \mathrm{~K}$ (internal wall: $2.22 \mathrm{~W} / \mathrm{m}^{2} \mathrm{~K}$ )

1. $20 \mathrm{~mm}$ Lime cement render

2. $140 \mathrm{~mm}$ Hollow ceramic block $(14 \times 19 \times 29 \mathrm{~cm})$

3. $20 \mathrm{~mm}$ Lime cement plaster

ceramic tiles added on the kitchen and bathroom walls

\section{Alvorada House}

External walls (north, east, and west)/Internal walls

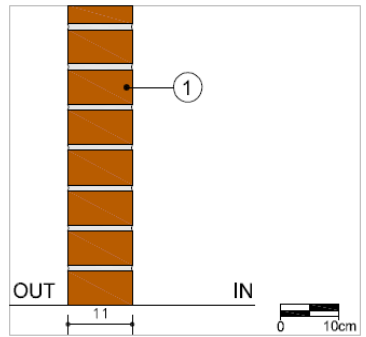

Solid ceramic brick wall, no finishing, $110 \mathrm{~mm}, 3.57 \mathrm{~W} / \mathrm{m}^{2} \mathrm{~K}$ (internal wall: $2.70 \mathrm{~W} / \mathrm{m}^{2} \mathrm{~K}$ )

1. $\quad 110 \mathrm{~mm}$ Solid ceramic brick $(11 \times 5 \times 22 \mathrm{~cm})$

Other external wall variations (south and west):

South: lime cement render and lime cement plaster added $\left(130 \mathrm{~mm}, 3.36 \mathrm{~W} / \mathrm{m}^{2} \mathrm{~K}\right) /$ West: lime cement render added $\left(120 \mathrm{~mm}, 3.46 \mathrm{~W} / \mathrm{m}^{2} \mathrm{~K}\right)$

Internal walls: lime cement plaster added on bedroom walls $\left(120 \mathrm{~mm}, 2.64 \mathrm{~W} / \mathrm{m}^{2} \mathrm{~K}\right) /$ ceramic tiles added on the kitchen and bathroom walls

External walls (west), in the kitchen area, up to $110 \mathrm{~cm}$ height from the floor (see wall projection in Figure 4)

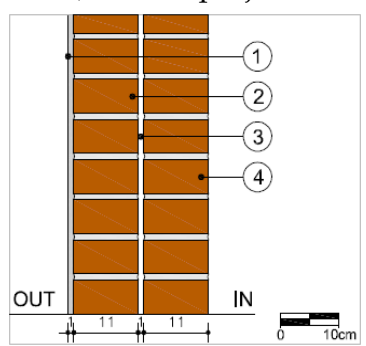

2-layer solid ceramic brick wall, lime cement render, $\sim 240 \mathrm{~mm}$, $1.82 \mathrm{~W} / \mathrm{m}^{2} \mathrm{~K}$

1. $10 \mathrm{~mm}$ Lime cement render

2. $110 \mathrm{~mm}$ Solid ceramic brick $(11 \times 5 \times 22 \mathrm{~cm})$

3. $\sim 10 \mathrm{~mm}$ air cavity (for building up)

4. $\quad 110 \mathrm{~mm}$ Solid ceramic brick $(11 \times 5 \times 22 \mathrm{~cm})$

Aluminium foil pitched roof, $133.15 \mathrm{~mm}, 0.92 \mathrm{~W} / \mathrm{m}^{2} \mathrm{~K}$

1. $10 \mathrm{~mm}$ clay roof tiles

2. Lathes $20 \times 50 \mathrm{~mm}$; ventilation bet cross-lathing

3. Rafters $20 \times 50 \mathrm{~mm}$; ventilation bet cross-rafters

4. $0.15 \mathrm{~mm}$ Aluminium foil

5. Rafters $70 \times 50 \mathrm{~mm}$; air bet cross-rafters

6. $12 \mathrm{~mm}$ Timber ceiling

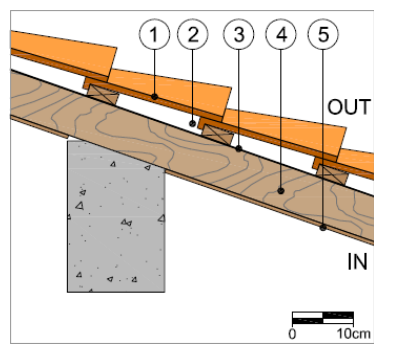

Aluminium foil pitched roof, $106.15 \mathrm{~mm}, 0.98 \mathrm{~W} / \mathrm{m}^{2} \mathrm{~K}$

1. $10 \mathrm{~mm}$ Roman clay roof tiles

2. Lathes $20 \times 50 \mathrm{~mm}$; ventilation bet cross-lathing

3. $\quad 0.15 \mathrm{~mm}$ Aluminium foil

4. Rafters $70 \times 50 \mathrm{~mm}$; ventilation bet cross-rafters

5. $12 \mathrm{~mm}$ Cedar lumber ceiling 


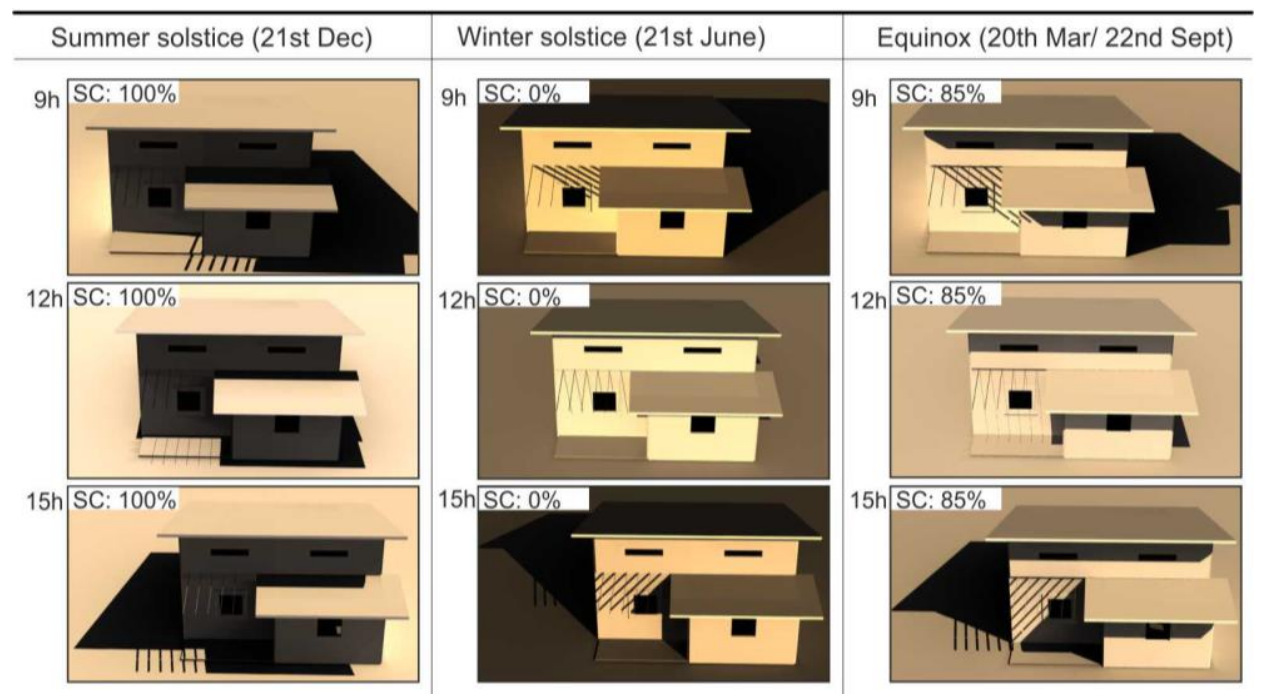

Figure 5. Alvorada House shading evaluation.

The characteristics of the geometry of the case studies are highlighted in Table 2. The Alvorada's internal volume combined with its open sheltered areas, impact on the exposed surface areas of the envelopes. Consequently, this associated to a reduced floor area means a higher form factor when compared to the other example. A high form factor indicates how spread out the form is, and this is usually less cost-efficient as it increases losses and gains that are influenced by the exposed outer surface of the building envelope.

Table 2. Case studies-geometry characteristics.

\begin{tabular}{|c|c|c|c|}
\hline \multicolumn{2}{|c|}{ Areas, Volumes and Other Factors } & MCMV House & Alvorada House \\
\hline \multicolumn{2}{|c|}{ Internal floor area $\left(\mathrm{m}^{2}\right)$} & 36.52 & 38.67 \\
\hline \multicolumn{2}{|c|}{ External floor area-including walls $\left(\mathrm{m}^{2}\right)$} & 43.83 & 43.00 \\
\hline \multicolumn{2}{|c|}{ Internal volume $\left(\mathrm{m}^{3}\right)$} & 108.80 & 130.70 \\
\hline \multicolumn{2}{|c|}{ Exposed external surface areas of the envelope $\left(\mathrm{m}^{2}\right)$} & 165.95 & 221.35 \\
\hline \multirow{6}{*}{$\begin{array}{l}\text { Breakdown of exposed external surface } \\
\text { areas of the envelope by orientation }\left(\mathrm{m}^{2}\right)\end{array}$} & South wall & $18.15(10.9 \%)$ & $22.52(10.2 \%)$ \\
\hline & East wall & $19.70(11.9 \%)$ & $24.33(11.0 \%)$ \\
\hline & North wall & $18.15(10.9 \%)$ & $31.89(14.4 \%)$ \\
\hline & West wall & $19.70(11.9 \%)$ & $24.33(11.0 \%)$ \\
\hline & Ground floor & $43.83(26.4 \%)$ & $49.43(22.3 \%)$ \\
\hline & Roof & $46.42(28.0 \%)$ & $68.75(31.1 \%)$ \\
\hline \multicolumn{2}{|c|}{$\begin{array}{l}\text { Form factor: 2-3 compact detached houses of two or three-storey; } 3-4 \text { less } \\
\text { compact detached houses [42]. }\end{array}$} & 4.55 & 5.72 \\
\hline \multicolumn{2}{|c|}{$\begin{array}{l}\text { Compactness: ratio of the internal volume of the building to its envelope } \\
\text { external surface area; desirable values: } 0.8-2.2 \mathrm{~m}[43]\end{array}$} & 0.65 & 0.59 \\
\hline
\end{tabular}

\section{Methodology}

The methodology of this study consisted of a literature review and two case studies analyses with the use of empirical data, dynamic building simulation and costing evaluation. The overall method consisted of simulating the thermal performance and costing the two houses as they are before implementing and analysing different optimisation levels. This optimisation was then quantified and a set of equations were created to facilitate the assessment of housing costs when improvements are aimed. This methodology allowed us to holistically evaluate the feasibility of the envelope improvements and compare the cost-effectiveness of the solutions adopted with the Brazilian context. The novelty of this study relied on the fact there are a very limited number of studies that look at fabric 
first concepts in Brazil and even fewer that consider regional differences such as cultural, economic, construction market and climatic.

\subsection{Dynamic Thermal Simulation and Calibration Methods}

The simulations were conducted through the use of TAS dynamic building simulations software by Environmental Design Solutions Ltd. [44] and climatic file produced by Roriz [18], which accounts the years between 2000 and 2010.

The simulations conditions of use comprised full occupancy (4 people) of the house with work activity varying according to the use of the space, lighting switched on in specific times of the day and adopting different thermal loads as per the use of space. Typical household equipment and appliances usage were adopted according to the Brazilian culture and habits [45-47], resulting in a daily energy consumption calculated to be $1.9 \mathrm{kWh}$ [7]. The resultant internal gains of MCMV and Alvorada houses were equivalent to 11.6 and $10.9 \mathrm{~W} / \mathrm{m}^{2}$, respectively. Note that these internal gains are much higher than the internal gains assumed by many energy efficient standards in European countries where the houses are immensely larger (nearly $100 \mathrm{~m}^{2}$ ) in comparison to the Brazilian affordable ones (e.g., MCMV internal gains is 5.5 times higher than gains assumed for Passivhaus house for a house size that is 3 times smaller than the typical Passivhaus house).

Empirical data of one-year monitoring of the Alvorada House was used to calibrate the corresponding housing model and establish relationship across the models. Data collected was ceded by NORIE and is shown in Morello [48]. Data of environmental variables such as globe temperature, dry bulb temperature, wet bulb temperature and relative humidity were collected in 2003-2004 (within the climatic file period), and the house was uninhabited during the monitoring. The simulation model was calibrated using measured performance data and assessed against two error indexes: the Mean Bias Error and the Root Mean Square Error as per ASHRAE Guideline [49]. The first index measures the consistency between the measured and simulated data while the second index measures the deviation of the measured and simulated data. The Mean Bias Error and Root Mean Square Error were calculated to be $0.7 \%$ and $5.6 \%$ between measured and simulated data, very lower than their limits of $10 \%$ and $30 \%$ established by ASHRAE Guideline [49], respectively. This showed a good agreement between the simulated and measured data, with a strong correlation of 0.93 .

\subsection{Precedents of the Building Envelope Optimisation}

Two building envelope combinations were selected from of a combination 108 building envelopes-12 different walls, 3 roofs, and 3 glazing types varied at a time based on a prior investigation and published in [29]. These demonstrated to be the best performing and the most cost-effective envelope among those envelopes investigated for the context of Brazilian affordable single-family residential buildings, shown in Table 3.

These envelope components were selected at first to meet the U-value of the national standards and optimisations were undertaken at two levels: up to Passivhaus levels (strict U-value) and to Passivhaus recommendations to mild climates (intermediate U-value). The rationale for that relies on investigating high thermal performance envelope solutions for the Brazilian context together with its adequacy and cost-effectiveness. The structure of the envelope components was defined based on a combination of what is typically used in the Brazilian construction and what is mostly used in high thermal performance buildings that would still be appropriate for Brazil according to market availability. In terms of the transparent element, double glazing of low emissivity was adopted as being the highest performance for the climate investigated due to the relatively mild characteristic of this climate and based on a Passivhaus study in different climatic zones [50]. In addition, the use of double glazing is very limited in the Brazilian domestic sector, being more associated to high-income households in areas of acoustical needs. Triple glazing is not commonly available in the Brazilian market. The authors acknowledge that the use of double glazing 
rather than triple glazing can work as a thermal bridge when the remaining building envelope has comparatively much lower U-values.

Table 3. Optimised envelopes adopted: named as the best performing and the most cost-effective envelopes, based on [29].

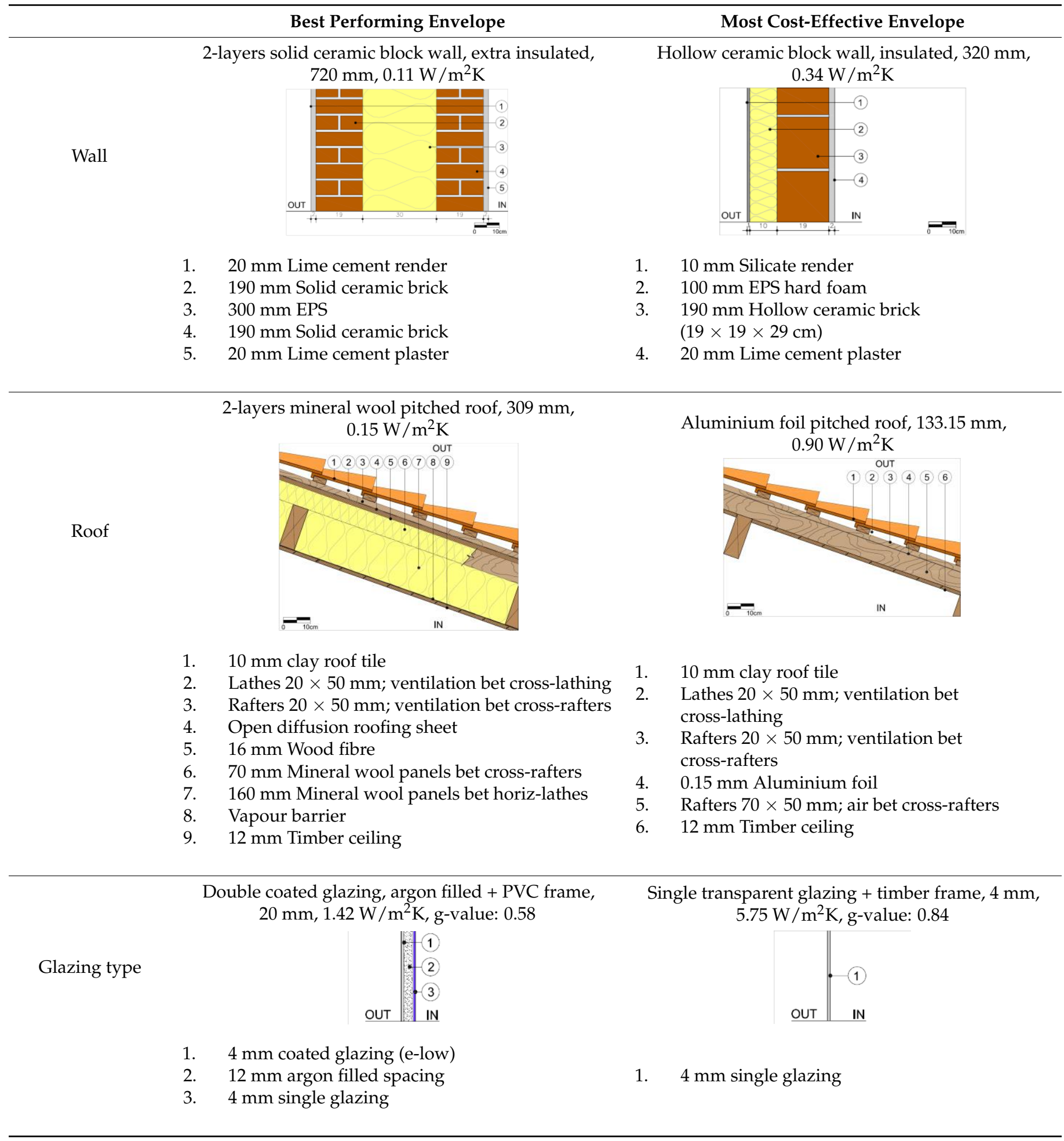

\subsection{Thermal Comfort Criteria}

The thermal comfort criteria used to analyse the results considered adaptive comfort models such as demonstrated in [51-56] as well as well-established practices in Brazilian 
thermal comfort research [57], which presupposes that people have a higher degree of acceptability with the indoor temperatures mainly when associated to naturally ventilated buildings. Acceptable comfort limits were calculated using $80 \%$ of acceptability according to adaptive ANSI/ASHRAE Standard 55 [53], which were found to be within the temperatures of approximately $18-29^{\circ} \mathrm{C}$, due to the seasonal characteristic of the climate. This comfort interval of $18-29^{\circ} \mathrm{C}$ was used to calculate cooling and heating demands in Table 4 . However, research also demonstrated that for the same climatic zone of Porto Alegre, people in sedentary activity and naturally ventilated environment preferred temperatures varying from nearly $20^{\circ} \mathrm{C}$ to $25^{\circ} \mathrm{C}$ [58]. In order to facilitate the analysis, accounting for different levels of acceptability to the occupants, three different comfort criteria were considered: narrow $\left(20-25^{\circ} \mathrm{C}\right)$, wide $\left(18-27^{\circ} \mathrm{C}\right)$, and extended $\left(18-29^{\circ} \mathrm{C}\right)$ comfort intervals. Selective ventilation was considered in a way that when the outdoor conditions were unfavourable, the windows were closed to avoid heat or cold coming inside the building. This aims to represent the ability of the occupants to actively act to restore their thermal comfort within their environment (e.g., open/close window; cold/warm drink; add/remove a clothing layer), while keeping the temperatures within the acceptable comfort criteria.

\subsection{Costing Method}

The cost analyses initially consisted of comparing the costs of as-built and optimised building envelopes for the case studies. The costs of the building envelopes were calculated based on the web database Tabela de Composições e Preços para Orçamentos (TCPO), 'Table for Pricing Engineering and Construction Projects' in English. TCPO is a 50-year old Brazilian construction database developed by PINI publishing of more than 5 thousand typical construction composition prices for each Brazilian state $[59,60]$. The web database is updated on a monthly basis based on the construction cost indexes at each location.

The costs analyses were undertaken in May 2015, prices were, then, updated to 2019 by applying annual inflation from 2016 onwards and converted from Brazilian Reais (BRL) to US dollars (USD) currency in June 2019 (BRL $3.78 \approx$ USD 1.00) [61]. The cost analyses considered the unitary cost per square metre of each envelope component (i.e., wall, roof, window frame, window glazing, and door), including material, labour costs, and compulsory labour taxes (equivalent to $129.34 \%$ of the labour costs for the context of Porto Alegre) through the extensive use of Excel Spreadsheets. When no information was available on the database of a specific material due to its innovativeness in the construction sector (e.g., low emissivity glazing), prices were quoted against key suppliers at the city investigated. Costing sample for an insulated wall is shown in Table 4.

Table 4. Example of the method developed for costing an insulated brick wall (the best performing envelope wall) using TCPO data [59], May 2015 prices, updated to 2019 with annual inflation applied from 2016 onwards, USD currency, BRL $3.78 \approx$ USD $1.00[61]-$ MCMV House.

\begin{tabular}{|c|c|c|c|c|c|c|c|c|c|}
\hline \multirow[b]{2}{*}{$\begin{array}{c}\text { Envelope } \\
\text { Component }\end{array}$} & \multirow[b]{2}{*}{$\underset{\left(m^{2}\right)}{\text { Quantity }}$} & \multicolumn{3}{|c|}{ Detailed Unitary Cost (per $\left.\mathrm{m}^{2}\right)$} & \multicolumn{4}{|c|}{ Calculated Cost } & \multirow[b]{2}{*}{$\begin{array}{c}\text { Cost per } \\
\text { Element } \\
\text { (USD) }\end{array}$} \\
\hline & & $\begin{array}{l}\text { Labour } \\
\text { (Hour) }\end{array}$ & $\begin{array}{l}\text { Labour } \\
\text { Cost } \\
\text { (USD/h) }\end{array}$ & $\begin{array}{c}\text { Material } \\
\left(\mathrm{USD} / \mathrm{m}^{2}\right)\end{array}$ & $\begin{array}{l}\text { Labour } \\
\text { (Hour) }\end{array}$ & $\begin{array}{l}\text { Labour } \\
\text { (USD) }\end{array}$ & $\begin{array}{c}\text { Labour Taxes } \\
127.95 \% \\
\text { (USD) }\end{array}$ & $\begin{array}{l}\text { Material } \\
\text { (USD) }\end{array}$ & \\
\hline \multirow{2}{*}{$\begin{array}{c}\begin{array}{c}2-\text { layer solid } \\
\text { brick }\end{array} \\
(9 \times 5.7 \times 19 \mathrm{~cm})\end{array}$} & \multirow{2}{*}{144.5} & 1.81 & $\begin{array}{c}\text { Servant } \\
1.20\end{array}$ & $\begin{array}{l}\text { Brick } \\
13.40\end{array}$ & \multirow{2}{*}{611.19} & \multirow{2}{*}{881.29} & \multirow{2}{*}{1127.61} & \multirow{2}{*}{3531.16} & \multirow{2}{*}{5540.06} \\
\hline & & 2.42 & $\begin{array}{c}\text { Brick layer } \\
1.62\end{array}$ & $\begin{array}{l}\text { Mortar } \\
11.03\end{array}$ & & & & & \\
\hline \multirow{2}{*}{ EPS $30 \mathrm{~cm}$} & \multirow{2}{*}{72.25} & 0.30 & $\begin{array}{c}\text { Servant } \\
1.20\end{array}$ & $\begin{array}{c}\text { Insulation } \\
31.64\end{array}$ & \multirow{2}{*}{43.35} & \multirow{2}{*}{61.19} & \multirow{2}{*}{78.30} & \multirow{2}{*}{2518.90} & \multirow{2}{*}{2658.39} \\
\hline & & 0.30 & $\begin{array}{c}\text { Brick layer } \\
1.62\end{array}$ & $\begin{array}{l}\text { Other } \\
3.22\end{array}$ & & & & & \\
\hline
\end{tabular}




\subsection{Equations Method}

A methodology to estimate the total building costs was developed in a format of equations using data from national standards, case studies, existing costing platform and typical regional construction indexes. This aimed to simplify the procedures for future costing evaluation in houses of similar typology, building envelope and levels of optimisations.

The costs of the whole building were estimated through the Brazilian standard NB12721 [62] (classifying the case studies as compact 1-storey single-family houses of area up to 58 square metres containing two bedrooms) and using the Custo Unitario Basico (CUB) methodology, 'Basic Unitary Cost' in English. CUB is a regional construction cost index per square metre calculated monthly according to the building typology $[63,64]$. Architectural design costs were also estimated using Conselho de Arquitetura e Urbanismo (CAU) methodology, 'Architecture and Urbanism Council's' in English, with the aim of evaluating the impact of the design on the overall house costs $[65,66]$. CAU's methodology uses the CUB index, the built area of the building and accounts different levels of complexity of the design that is likely to occur in those optimised buildings. A set of equations were then developed to estimate construction and design costs in a simplified and efficient manner.

\section{Results}

The results were analysed in three stages: firstly, the thermal comfort levels of each case were evaluated, secondly the running costs of the house in each case were assessed, and finally the building and running costs to generate overall costs for each case were aggregated.

\subsection{Thermal Comfort Evaluation}

Frequency of temperatures for a year-period was shown for as-built and optimised building envelope scenarios (Table 5 and Figure 6). In these figures, the frequency of temperatures within the narrow thermal interval of $20-25^{\circ} \mathrm{C}$ was coloured in white. The frequency of temperatures below the lower thermal comfort interval was marked in blue to represent a gradual increase in thermal discomfort due to cold as the temperature decreases. Temperatures above the upper thermal comfort interval were marked varying from yellow to red to demonstrate the intensity of the thermal discomfort as the temperature increases. The outdoor conditions were within the thermal comfort for nearly $31 \%, 52 \%$, and $57 \%$ for the narrow $\left(20-25^{\circ} \mathrm{C}\right)$, wide $\left(18-27^{\circ} \mathrm{C}\right)$ and extended $\left(18-29^{\circ} \mathrm{C}\right)$ thermal comfort criteria, respectively.

Table 5. Percentages of thermal comfort according to different comfort criteria (marked in bold, the increase in thermal comfort of the optimised envelopes related to as-built envelope within each comfort criterion).

\begin{tabular}{|c|c|c|c|c|c|c|}
\hline $\begin{array}{l}\text { Thermal } \\
\text { Comfort } \\
\text { Criterion }\end{array}$ & $\begin{array}{c}\text { External } \\
\text { Temperatures }\end{array}$ & Envelope & MCMV & $\begin{array}{l}\text { Increase in thermal } \\
\text { Comfort } \\
\text { Related to As-Built } \\
\text { Envelope }\end{array}$ & Alvorada & $\begin{array}{c}\text { Increase in Thermal } \\
\text { Comfort } \\
\text { Related to As-Built } \\
\text { Envelope }\end{array}$ \\
\hline \multirow{3}{*}{$20-25^{\circ} \mathrm{C}$} & \multirow{3}{*}{$31 \%$} & As-built & $45 \%$ & & $42 \%$ & \\
\hline & & Best performing & $79 \%$ & $(\uparrow 76 \%)$ & $72.5 \%$ & $(\uparrow 73 \%)$ \\
\hline & & Most cost-effective & $63 \%$ & $(\uparrow 40 \%)$ & $61 \%$ & $(\uparrow 45 \%)$ \\
\hline \multirow{3}{*}{$18-27^{\circ} \mathrm{C}$} & \multirow{3}{*}{$52 \%$} & As-built & $81 \%$ & & $78 \%$ & \\
\hline & & Best performing & $99 \%$ & $(\uparrow 22 \%)$ & $98 \%$ & $(\uparrow 26 \%)$ \\
\hline & & Most cost-effective & $95 \%$ & $(\uparrow 17 \%)$ & $93 \%$ & $(\uparrow 19 \%)$ \\
\hline \multirow{3}{*}{$18-29^{\circ} \mathrm{C}$} & \multirow{3}{*}{$57 \%$} & As-built & $87 \%$ & & $81 \%$ & \\
\hline & & Best performing & $99 \%$ & $(\uparrow 14 \%)$ & $98 \%$ & $(\uparrow 21 \%)$ \\
\hline & & Most cost-effective & $96 \%$ & $(\uparrow 10 \%)$ & $95 \%$ & $(\uparrow 17 \%)$ \\
\hline
\end{tabular}




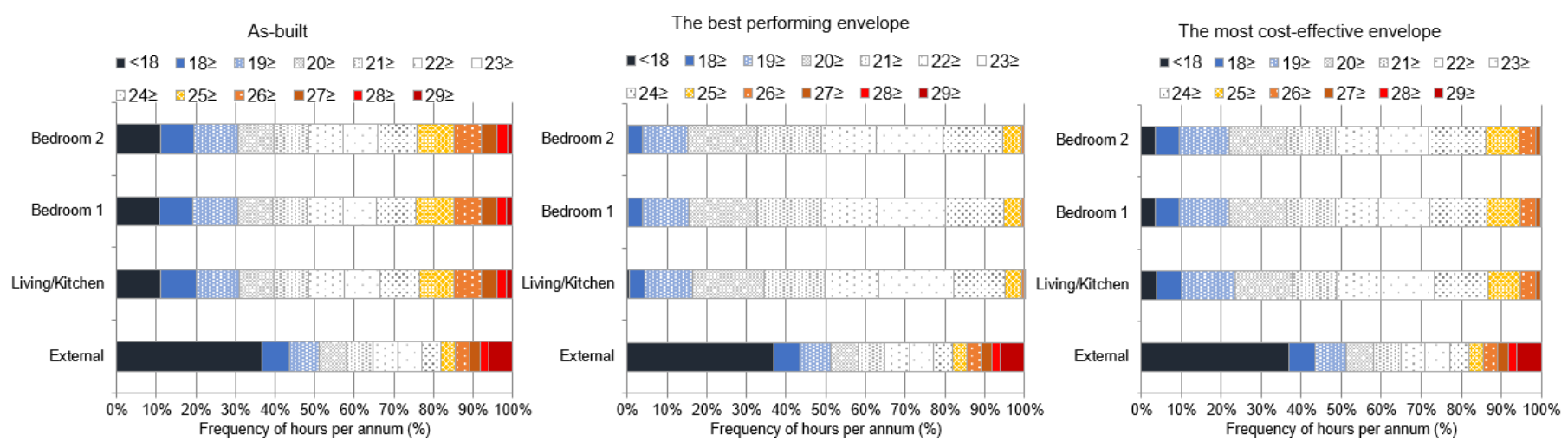

Figure 6. MCMV House-as-built and optimised building envelope scenarios.

For the as-built scenario, the MCMV house revealed that for $45 \%$ of the time, the indoor temperatures were within the comfort interval of $20-25^{\circ} \mathrm{C}$, and the comfort levels were increased to $81 \%$ and $87 \%$ if the wide and extended thermal comfort criteria were considered, respectively. Comparatively, the Alvorada House indicated slight lower thermal comfort than MCMV house. The comfort levels achieved in Alvorada's House as-built represented $42 \%, 78 \%$ and $81 \%$ of the time for the narrow, wide, and extended thermal comfort criteria, respectively. Lower levels of thermal comfort associated to the Alvorada's house were mostly attributed to its different materials and shape of the building.

For the context of the optimised scenarios, adopting best performing envelope for both case studies, the MCMV house would have the internal comfort extended to $79 \%$ of the time for the narrow thermal comfort criterion and $99 \%$ of the time for the wide and extended thermal comfort criteria. The Alvorada House would achieve indoor thermal comfort in $72.5 \%$ of the time for the narrow thermal comfort criterion and $98 \%$ of the time for the wide and extended thermal comfort criteria, then, very similar to MCMV house results.

Adopting the most cost-effective scenario, the MCMV house would have the indoor conditions equivalent to $63 \%, 95 \%$ and $96 \%$ of the time within the thermal comfort criteria of 20-25, $18-27$, and $18-29{ }^{\circ} \mathrm{C}$, respectively. Based on the same envelope, the Alvorada House would achieve similar levels equivalent to $61 \%, 93 \%$ and $95 \%$ of the time within the thermal comfort criteria, respectively. The difference in the results between the two case studies is mostly attributed to the more spread-out form of the Alvorada House in comparison to the MCMV house. Annual percentages of thermal comfort are summarised comparatively in Figures 7-9.
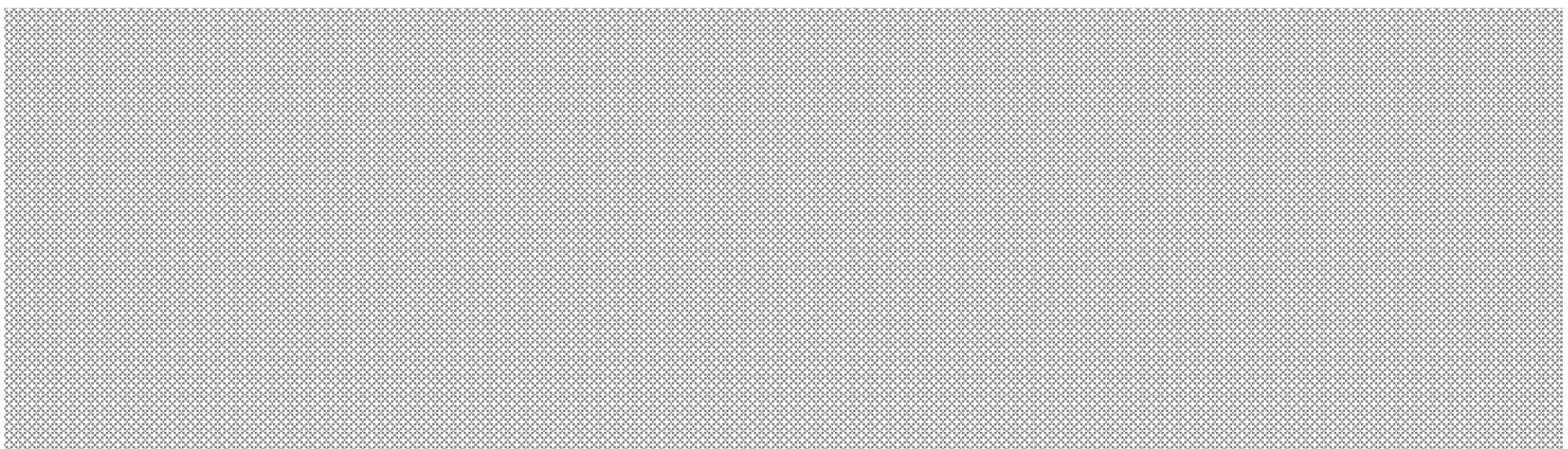

Figure 7. Alvorada House—as-built and optimised building envelope scenarios. 


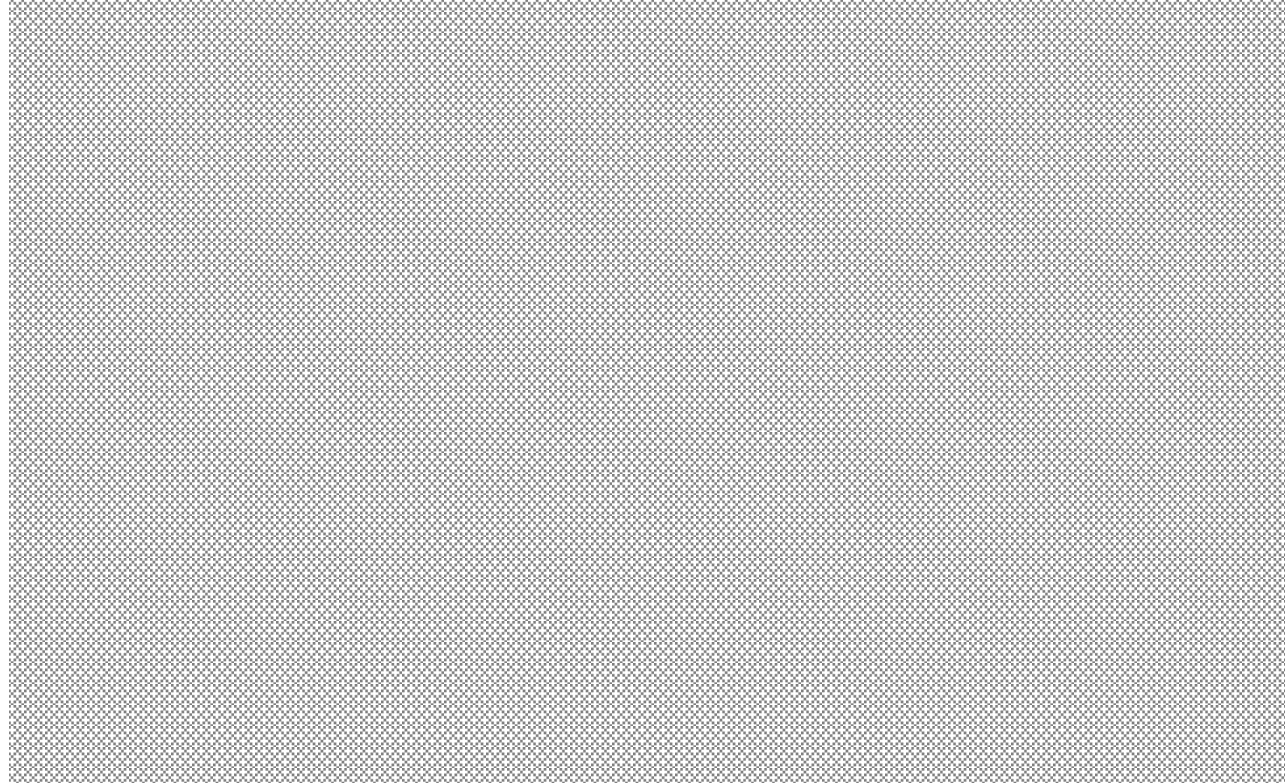

Figure 8. MCMV House-percentage of thermal comfort for different thermal comfort criteria.

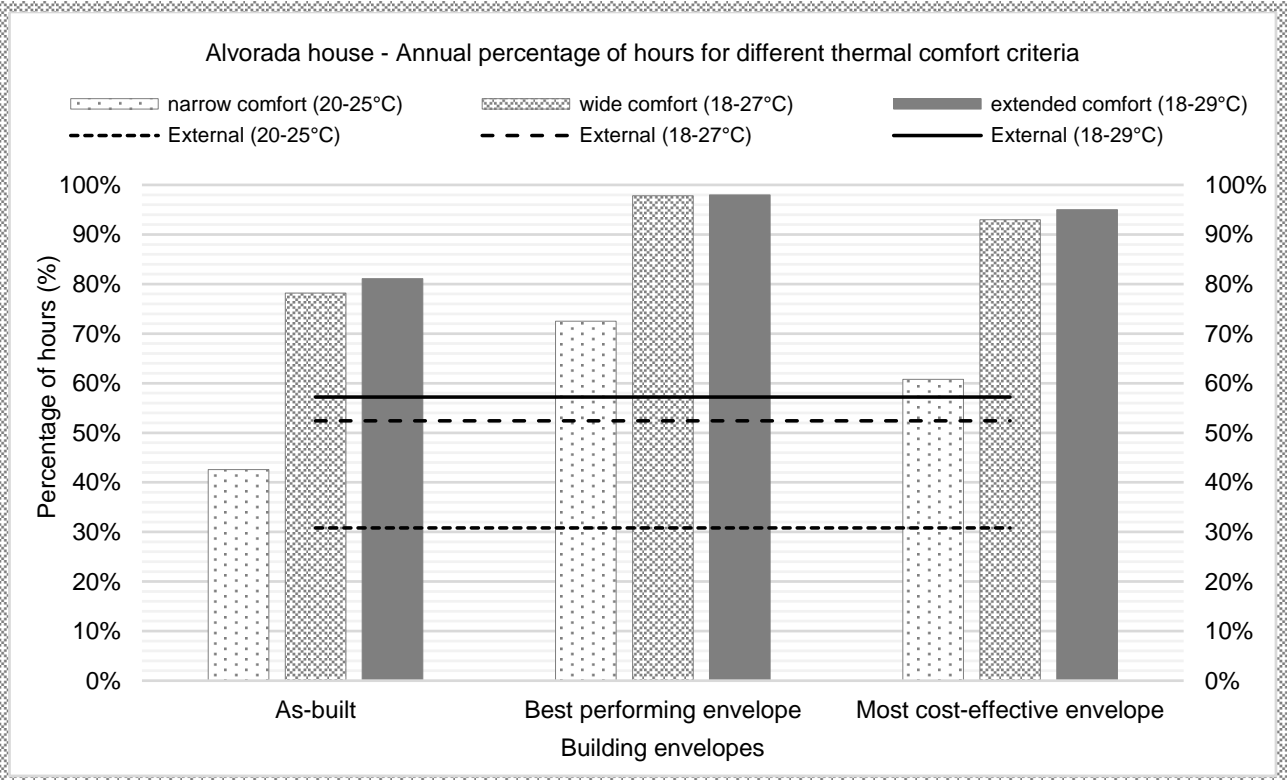

Figure 9. Alvorada House-percentage of thermal comfort for different thermal comfort criteria.

Similar results were obtained when adopting an optimised envelope with the use of selective ventilation. Indoor thermal comfort conditions remained at similar figures for the optimised envelopes, with indoor levels only significantly improving for the case of the most cost-effective envelope at narrow comfort range, which increased the comfort levels from $63 \%$ to $66 \%$ of the time and from $61 \%$ to $64 \%$ of the time in MCMV and Alvorada houses, respectively.

A conditioned scenario was also considered for informative purposes only to estimate the annual energy demand to keep the indoor temperatures within the comfort range of $20-25{ }^{\circ} \mathrm{C}$ (mixed-mode ventilation scenario). This meets both heating and cooling demands. Results revealed the same tendency shown in the thermal comfort analyses (Figure 10).The Alvorada House had slightly higher demands due to its high internal volume and number of exposed surfaces to the environment. The energy demand of the envelope as-built corresponded to nearly $31 \mathrm{kWh} / \mathrm{m}^{2}$ for the MCMV House and $45 \mathrm{kWh} / \mathrm{m}^{2}$ for the Alvorada House. With the adoption of the best performing envelope, 
the energy demand would be reduced to approximately 4 and $5 \mathrm{kWh} / \mathrm{m}^{2}$ for the MCMV and Alvorada houses, respectively. With the use of the most cost-effective envelope, the energy demand would represent nearly $11 \mathrm{kWh} / \mathrm{m}^{2}$ for both houses.

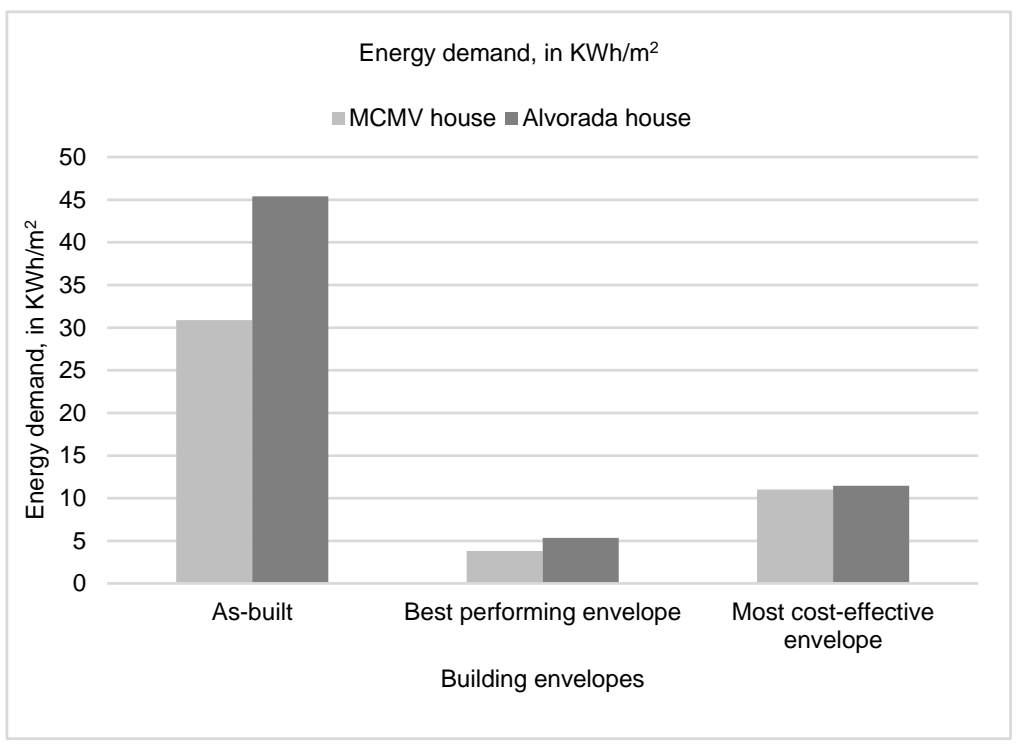

Figure 10. Case studies-estimated annual energy demand for as-built and optimised building envelope scenarios.

\subsection{Running Costs Assessment}

Figure 11 shows the houses' running costs for a one-year period and, then, 50-year period, estimated to be the Brazilian houses' life span, established by the Brazilian standards NBR 15575 [25]. The running costs slightly differed between the two case studies for the as-built scenario, mainly due to their distinct building envelopes (Alvorada's envelope has higher U-values). For the optimised scenarios, the running costs were slightly higher on the Alvorada House than on the MCMV House mainly attributed to the geometry of the house.

Running costs for a one-year period for the MCMV House corresponded to circa of USD 252, 31, and 90 for the standard, best performing and most cost-effective envelopes, respectively. For the Alvorada house, this represented circa of USD 393, 46, and 99. During the life span of the houses, applying $6 \%$ a year inflation, the running costs of the MCMV house would correspond to over USD 4390, 540, and 1568 for the standard, best performing and most cost-effective envelopes, whereas the costs of the Alvorada House would correspond to USD 6833, 805, and 1725, respectively.

Figure 12 shows the calculated building envelope costs using the TCPO database. The best performing envelope showed to cost nearly 4 times more than the as-built envelopes (3.8 more for the MCMV and 4.1 more for the Alvorada) and the most cost-effective envelopes had costs of only nearly 1.5 times more than the as-built envelopes (1.4 more for the Alvorada and 1.6 for the MCMV). 



Figure 11. Case studies-estimated running costs: 1-year and 50-year (with 6\%-year inflation) scenarios, USD currency.

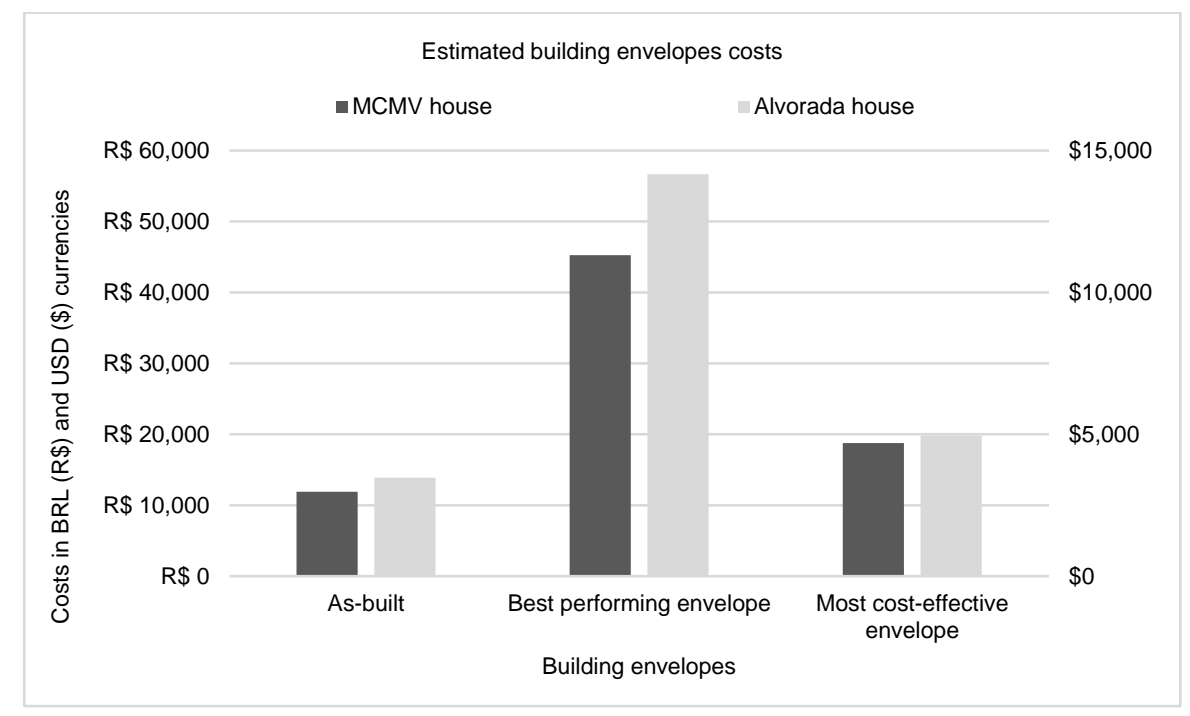

Figure 12. Case studies—estimated main building envelope costs, USD currency. 


\subsection{Building Costs Evaluation}

The analyses suggested that the best performing envelope and the most cost-effective envelope would add $57 \%$ and $12 \%$ more to the overall typical costs for the MCMV house and this would represent $65 \%$ and $9 \%$ more for the Alvorada house, respectively (Table 6).

Table 6. Case studies—estimated overall housing costs.

\begin{tabular}{ccc}
\hline & MCMV House & Alvorada House \\
\hline Estimated house costs, USD currency & $15,549.54$ & $17,519.31$ \\
\hline $\begin{array}{c}\text { Additional cost expenses on the overall building- } \\
\text { Best performing envelope, in percentage }\end{array}$ & $57 \%$ & $65 \%$ \\
\hline $\begin{array}{c}\text { Additional cost expenses on the overall building- } \\
\text { Most cost-effective envelope, in percentage }\end{array}$ & $12 \%$ & $9 \%$ \\
\hline
\end{tabular}

The overall costs of designing and constructing this housing type were estimated using equations for the scenarios investigated (Equations (1)-(5)). The equations can be used to help estimate the cost of the optimisation process, a potentially time-consuming process, in a simplified manner. They were formulated taking into account the share of contribution of each construction activity (e.g., labour, material, administrative and equipment expenses) represented by the use of an updated CUB index, then multiplied by the built area of the housing (it should account for the external walls). The equations were then adjusted with the indexes calculated based on each envelope configuration (as-built or optimised), considering the changes needed in terms of the design and management. The design and construction of the optimised building envelopes were assumed to be of higher complexity than the standard envelopes as they deviate of common Brazilian practices and therefore, adopted according to the indexes of the CAU's methodology [65,66].

The costs of designing and constructing single-family residential houses as-built $(a b)$ ' $C_{a b}$ ' for both case studies can be estimated using Equation (Table 6), where ' $C_{(f x)}$ ' is the cost of housing design and construction according to the selected building envelopes; ' $p$ ' is the standard price of housing construction obtained through the multiplication of the CUB by the built area of the house; and ' $d_{(f x}$ ' (as-built or optimised) is the cost of the architectural design, obtained through the multiplication of the CUB by the built area of the house and applied coefficient due the complexity of the building envelope ( 0.733 as typically found or 0.11 for optimised envelopes). The cost of the MCMV house optimised envelopes (the best performing ( $b p)^{\prime} C_{M C M V, b p}$ ' and the most cost-effective (ce) ' $C_{M C M V, c e}$ ') can be estimated using Equations (2) and (3), while the costs of Alvorada House (Alv) optimised envelopes (the best performing ' $C_{A l v, b p}$ ' and the most cost-effective ' $C_{A l v, c e}$ ') can be calculated through Equations (4) and (5), respectively.

The findings suggest that the use of the cost-effective envelope could be a reasonable alternative to address the thermal comfort while reducing potential running costs without considerably increasing the upfront costs.

$$
\begin{gathered}
C_{a b}=p \times 1.17+0.733 d_{\text {as built }} \\
C_{M C M V, b p}=(p \times 1.57) \times 1.17+0.11 d_{\text {optimised }} \\
C_{M C M V, c e}=(p \times 1.12) \times 1.17+0.11 d_{\text {optmised }} \\
C_{A l v, b p}=(p \times 1.65) \times 1.17+0.11 d_{\text {optimised }} \\
C_{\text {Alv }, b p}=(p \times 1.65) \times 1.17+0.11 d_{\text {optimised }}
\end{gathered}
$$

\section{Discussion}

Thermal comfort evaluation revealed that the Alvorada House, although it was built integrating passive design strategies of bioclimatic architecture for the climate of Porto 
Alegre, delivered slightly lower levels of indoor thermal comfort when compared to the MCMV house. Three main aspects should be discussed.

Firstly, in terms of the building envelope components, the Alvorada House was designed nearly a decade before the start of the MCMV housing programme. Even though significant changes have not been promoted in the design of the affordable and mass housing as shown in [3], the Alvorada House was designed before the Brazilian performance standard NBR15575 [25-27,67], which came into a force in 2015, and its envelope have higher thermal transmittance values, compromising the overall indoor thermal comfort of the house.

Secondly, with regard to the design, the MCMV house was adopted in this work under an optimised scenario, meaning that it was ideally considered north-south oriented; north windows rather than in other orientations were prioritised and maximised; north windows size appropriately placed to deliver summer shading while allowing direct solar radiation in winter. Unfortunately, this condition is not the reality of the use of housing model across the country, but it highlights its potential to deliver similar levels of thermal comfort of those designs that adopted a range of passive design strategies to increase thermal comfort. Comparatively, the Alvorada house could not have some of its passive design strategies evaluated such as the ventilated roof and the west shading, characteristics that would positively affect its thermal performance.

Thirdly, while the Alvorada house undeniably promoted more spacious rooms due to its double-height, while promoting increased ventilation (through stack effect); it created not only a building of potential better quality, but also a more interesting and appealing architectural piece than the monotonous and repetitive design of the MCMV house. This architecture was able to combine traditional and local construction methods and materials with an affordable approach. However, as consequence, its envelope surfaces were $33 \%$ higher for a similar useful housing area. This impacted both costs and indoor thermal comfort, suggesting that the exposed envelope seems to be an important aspect not only in those climates of colder temperatures but also important where there are heating or cooling demands, even in lesser degrees.

The use of optimised envelopes seemed to be able to reduce significantly the discomfort hours and these showed to be more significant for the narrowest comfort criterion. This would indicate a much higher percentage of occupants satisfied with their indoor environment. Figures 13 and 14 illustrates the magnitude of the improvement using heating (temperature base of $20^{\circ} \mathrm{C}$ ) and cooling (temperature base of $25^{\circ} \mathrm{C}$ ) degree-hours.
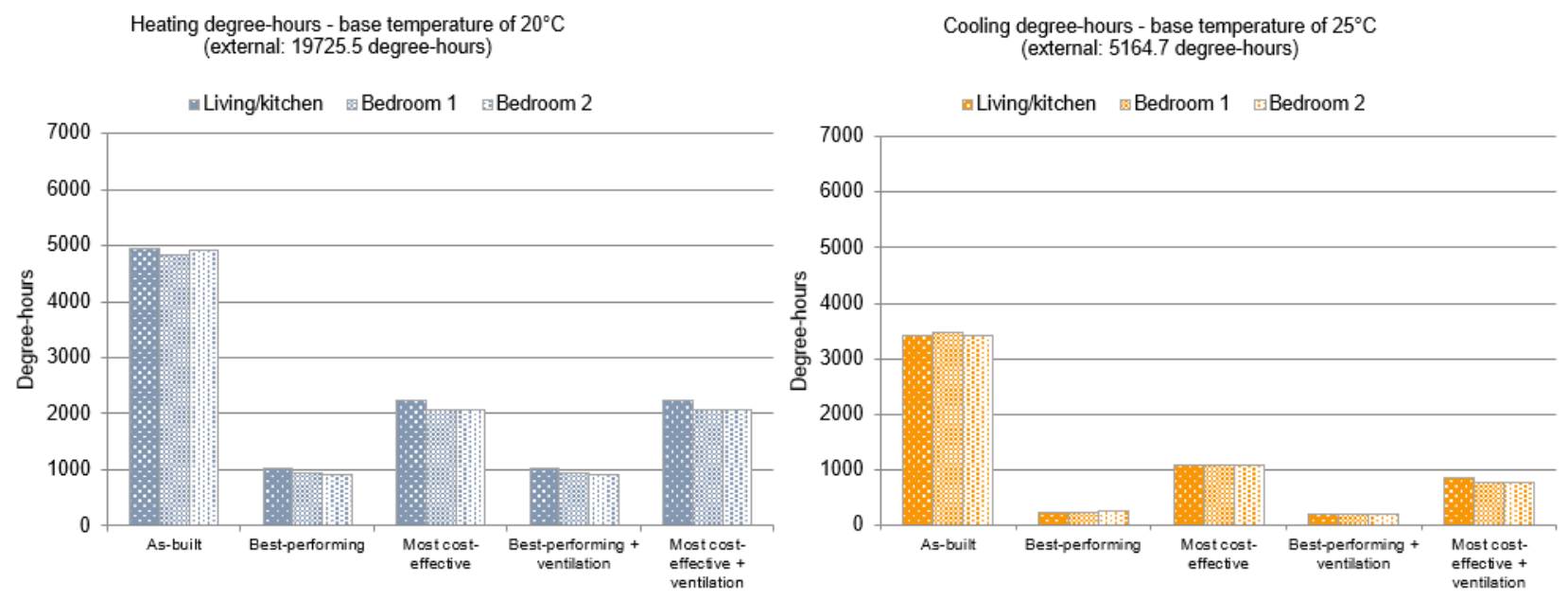

Figure 13. MCMV House-cooling and heating degree-hours-20-25 ${ }^{\circ} \mathrm{C}$. 

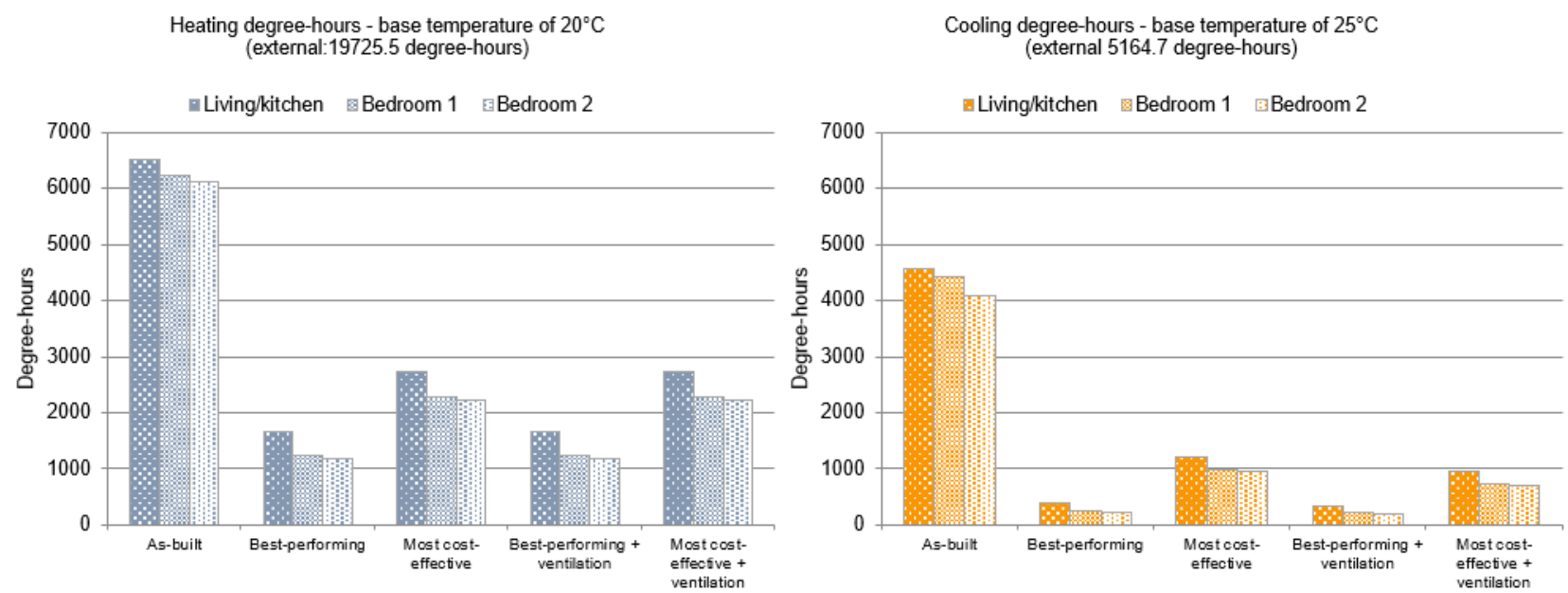

Figure 14. Alvorada House — cooling and heating degree-hours-20-25 ${ }^{\circ} \mathrm{C}$.

The ventilation results across the case studies suggest a limited impact on the thermal comfort levels, although the ventilation breezes have a positive impact on the comfort perception of the occupants. These results corroborate those observed in Triana, Roberto Lamberts [10]. Ventilation showed to be more evident when combined with the most-cost effective envelope and a reduction of up to $29 \%$ and $28 \%$ in the degree-hours (thermal discomfort) for the MCMV and Alvorada houses was showed for this ventilated scenario when compared to a non-ventilated one, respectively (see Figures 13 and 14).

Running costs assessment highlighted the importance of the exposed envelope surfaces to the environment even in buildings of the same typology, similar areas and using the same envelope components. Alvorada house had running costs $56 \%, 49 \%$ and $10 \%$ higher than the MCMV house for standard, best performing and most cost-effective envelopes, respectively, which were mostly attributed to its geometry and shape.

The introduction of the cost-effective envelope indicated the need for revisiting the delivery of affordable homes. While these optimised envelopes do impact on the up-front costs of the dwellings estimated to be 1.5 times more than the typical standard envelopes, in a long-term run of housing, they are able to reduce considerably the need for active means to achieve thermal comfort. It showed to be easily payable within the first 10 years of the house run for the case studies. The calculated payback period was estimated to be 9 and 5 years for the MCMV and Alvorada houses, respectively.

Building Costs Calculation highlighted the regionality of the Brazilian construction market and lack of innovativeness in the sector specially within the middle and lowereconomic classes. The enormous disparities with the prices of the most performing envelopes and the most cost-effective envelopes were given to the fact of the limited trade-in in the housing construction sector of some products impacting on the overall building costs (e.g., double coated glazing, PVC windows, external insulation materials). The developed equations were able to account for this regionality in both costs and labour. The method developed showed to be replicable when using regional indexes, available in the construction sector.

\section{Conclusions}

In this work, we assessed how the optimisation of the building envelope in affordable single-family residential buildings could result in greater thermal comfort, and what the cost implications are of implementing this. The findings reveal that there is a great scope for building envelope optimisation in these buildings, with potential for improving the thermal comfort in up to $76 \%$ and $73 \%$, respectively, when a narrow comfort band $\left(20-25^{\circ} \mathrm{C}\right)$ was considered. However, that would come at a premium of $57 \%$ cost increase for the MCMV house and $65 \%$ for the Alvorada house. Building envelope optimisation options with lower upfront costs of $12 \%$ and $9 \%$, respectively, also showed important improvement on the 
indoor thermal conditions in up to $40 \%$ and $45 \%$ more than the original envelope when the narrow comfort criterion was considered.

The most cost-effective envelopes had up-front costs 1.5 times greater than the typical standard envelopes, payable within the first 10 years of the house's lifespan for the case studies. In the long-term, they are able to considerably reduce the need for active means to achieve thermal comfort.

The developed equations presented in this paper can be used to simplify the timeconsuming process of costing the design and construction of a building in an efficient and easy way for those typical and improved building envelopes of similar typology. By adopting available regional indexes, the equations can be easily adapted for different locations.

Author Contributions: Conceptualization, R.T.; literature review R.T. and M.Z.; methodology, R.T., L.R. and M.G.; software, R.T.; validation, R.T.; writing—original draft preparation, R.T.; writingreview and editing, R.T, L.R., M.G. and M.Z.; supervision, L.R. and M.G. All authors have read and agreed to the published version of the manuscript.

Funding: This research was funded by the Improvement of Higher Education Personnel (CAPES) and the University of Nottingham.

Acknowledgments: The first author would like to acknowledge the Coordination for the Improvement of Higher Education Personnel (CAPES) and the University of Nottingham for their support. Our gratitude also goes to the 'Núcleo Orientado para a Inovação da Edificação' (NORIE) of the Department of Civil Engineering of the Federal University of Rio Grande do Sul (UFRGS) for providing the researchers with the Alvorada House empirical data.

Conflicts of Interest: The authors declare no conflict of interest.

\section{References}

1. Governo do Brasil. Governo Federal Garante Investimentos Para Continuidade do Minha Casa, Minha Vida. Available online: http://www.brasil.gov.br/noticias / cidadania-e-inclusao/2019/04/governo-federal-garante-investimentos-paracontinuidade-do-minha-casa-minha-vida/\#conteudo (accessed on 25 June 2019).

2. IBGE. Censo Demográfico 2010: Caracteristias da População e dos Domicilios-Resultados do universo; Instituto Brasileiro de Geografia e Estatística (IBGE): Rio de Janeiro, Brazil, 2011.

3. Kowaltowski, D.C.C.K.; Muianga, E.A.D.; Granja, A.D.; Moreira, D.d.C.; Bernardini, S.P.; Castro, M.R. A critical analysis of research of a mass-housing programme. Build. Res. Inf. 2019, 47, 716-733. [CrossRef]

4. Triana, M.; Roberto Lamberts, R.; Sassiba, P. Characterisation of representative building typologies for social housing projects in Brazil and its energy performance. Energy Build. 2015, 87, 524-541. [CrossRef]

5. EPE. Brazilian Energy Balance 2012-Year 2011; Empresa de Pesquisa Energética (EPE): Rio de Janeiro, Brazil, 2012.

6. EPE. Brazilian Energy Balance 2013-Year 2012; Empresa de Pesquisa Energética (EPE): Rio de Janeiro, Brazil, 2013.

7. Tubelo, R. The Application of the Fabric First Approach to Improve Thermal Comfort and Energy Efficiency in Affordable Housing in Southern Brazil; University of Nottingham: Nottingham, UK, 2016.

8. EPE. Nota Técnica EPE 030/2018-Uso de ar Condicionado no Setor Residencial Brasileiro: Perspectivas e Contribuições Para o Avanço em Eficiência Energética [Technical Note EPE 030/2018-The Use of Air Conditioning in the Brazilian Residential Sector: Perspectives and Contributions to the Advancement in Energy Efficiency; Empresa de Pesquisa Energética (EPE): Brasília, Brazil, 2018.

9. Ghisi, E.; Gosch, S.; Lamberts, R. Electricity end-uses in the residential sector of Brazil. Energy Policy 2007, 35, 4107-4120. [CrossRef]

10. Triana, M.; Roberto Lamberts, R.; Sassiba, P. Should we consider climate change for Brazilian social housing? Assessment of energy efficiency adaptation measures. Energy Build. 2018, 158, 1379-1392. [CrossRef]

11. McKinsey \& Company. Pathways to a Low Carbon Economy for Brazil; McKinsey \& Company: São Paulo, Brazil, 2012.

12. ABNT. NBR 15220-3: Thermal Performance in Buildings_Part 3: Brazilian Bioclimatic Zones and Building Guidelines for Low-Cost Houses; Associação Brasileira de Normas Técnicas (ABNT): Rio de Janeiro, Brazil, 2005.

13. Alvares, C.; Stape, J.; Sentelhas, P.; Goncalves, J.; Sparovek, G. Koppen's climate classification map for Brazil. Meteorol. Z. 2014, 22, 711-728. [CrossRef]

14. Tubelo, R.; Rodrigues, L.; Gillott, M. Building Envelope Optimisation for Low-Income Housing in Southern Brazil. In Proceedings of the PLEA 2017-33rd Conference on Passive and Low Energy Architecture: Design to Thrive, Edinburgh, UK, 3-5 July 2017; pp. $4373-4380$. 
15. Tubelo, R. Análise do Desempenho Térmico de Edificações Escolares: Estudo de caso do Centro de Educação Profissional do Vale do Caí e da Escola de Ensino Fundamental Frei Pacífico. Master's Thesis, Federal University of Rio Grande do Sul (UFRGS), Porto Alegre, Brazil, 2011.

16. DeKay, M.; Brown, G.Z. Sun, Wind \& Light: Architectural Design Strategies, 3rd ed.; John Wiley \& Sons: Hoboken, NJ, USA, 2014.

17. Lamberts, R.; Dutra, L.; Pereira, F. Eficiência Energética na Arquitetura, 3rd ed.; ELETROBRAS/PROCEL: Rio de Janeiro, Brazil, 2014.

18. Roriz, M. Arquivos Climáticos em Formato EPW [Climatic Files in EPW Format]; Associação Nacional de Tecnologia do Ambiente Construído (ANTAC): São Carlos, Brazil, 2012.

19. INPE-CCST. Dangerous Climate Change in Brazil: A Brazil-UK Analysis of Climate Change and Deforestation Impacts in the Amazon; Instituto Nacional de Pesquisas Espaciais (INPE) \& Met Office Hadley Centre: Brazil \& UK, 2011.

20. IPCC. Climate Change 2007: The Physical Science Basis; Cambridge University Press: Cambridge, UK, 2007.

21. IPCC. Climate Change 2014: Synthesis Report; Intergovernmental Panel on Climate Change (IPCC): Geneva, Switzerland, 2014.

22. Rubel, F.; Kottek, M. Observed and projected climate shifts 1901-2100 depicted by world maps of the Köppen-Geiger climate classification. Meteorol. Z. 2010, 19, 135-141. [CrossRef]

23. Rubel, F.; Kottek, M. Observed and Projected Climate Shifts SHIFTS 1901-2100 by World Maps of the Kopppen-Geiger Climate Classification. 2019. Available online: http:/ / koeppen-geiger.vu-wien.ac.at/shifts.htm (accessed on 20 January 2021).

24. National Weather Service. The Heat Index Equation by Lans P. Rothfusz. Available online: https://www.wpc.ncep.noaa.gov/ html/heatindex_equation.shtml (accessed on 8 August 2019).

25. ABNT. NBR 15575-1: Residential Buildings_Performance-Part 1: General Requirements; Associação Brasileira de Normas Técnicas (ABNT): Rio de Janeiro, Brazil, 2013.

26. ABNT. NBR 15575-4: Residential Buildings_Performance-Part 4: Requirements for Internal and External Wall Systems; Associação Brasileira de Normas Técnicas (ABNT): Rio de Janeiro, Brazil, 2013.

27. ABNT. NBR 15575-5: Residential Buildings_Performance—Part 5: Requirements for Roofing Systems; Associação Brasileira de Normas Técnicas (ABNT): Rio de Janeiro, Brazil, 2013.

28. Pacheco, M.; Lamberts, R. Assessment of technical and economical viability for large-scale conversion of single family residential buildings into zero energy building in Brazil: Climatic and cultural considerations. Energy Policy 2013, 63, 716-725. [CrossRef]

29. Tubelo, R.; Rodrigues, L.; Gillott, M.; Gonçalves Soares, J.C. Cost-effective envelope optimisation for social housing in Brazil's moderate climates zones. Build. Environ. 2018, 133, 213-227. [CrossRef]

30. Schnieders, J.; Feist, W.; Rongen, L. Passive houses for different climate zones. Energy Build. 2015, 105, 71-87. [CrossRef]

31. Passive House Institute. Passive House Requirements. Available online: https://passivehouse.com/02_informations/02_passivehouse-requirements /02_passive-house-requirements.htm (accessed on 22 January 2021).

32. James, M.; Bill, J. Passive House in Different Climates: The Path to Net Zero; Routledge: New York, NY, USA, 2016.

33. Mitchell, R.; Natarajan, S. Overheating risk in Passivhaus dwellings. Build. Serv. Eng. Res. Technol. 2019, 40, 446-469. [CrossRef]

34. McLeod, R.S.; Hopfe, C.J.; Kwan, A. An investigation into future performance and overheating risks in Passivhaus dwellings. Build. Environ. 2013, 70, 189-209. [CrossRef]

35. Passive House Intitute. Passive House Planning Package (PHPP): The Energy Balance and Design Tool for Efficient Buildings and Retrofits; Version 9; Passive House Intitute (PHI): Darmstadt, Germany, 2015.

36. Bere, J. An Introduction to Passive House; RIBA Publishing: London, UK, 2013.

37. Oettl, F. 'Green' Austrian Embassy Jakarta. In Proceedings of the 16th International Passive House Conference (iPHA), Hanover, Germany, 4-5 May 2012.

38. Yeh, S.-C. Bangkok First Concrete Passive House. In Proceedings of the 24th International Passive House Conference, Online, 17 September-8 October 2020.

39. Database, P.H. Passive House Database. Passive House Institute, the Passivhaus Dienstleistung GmbH, the IG Passivhaus Deutschland and the iPHA (International Passive House Association) and Affiliates; Passivhaus Institut GmbH: Darmstadt, Germany, 2020.

40. Ministério das Cidades. Programa Minha Casa Minha Vida/FAR: Especificações Mínimas Casa [My House, My Life Housing Programme: Minimum House Requirements]. Available online: http:/ /www.cidades.gov.br/images/stories/ArquivosSNH/ ArquivosPDF/Especificacoes/especificacoes_casa_port168.pdf (accessed on 6 January 2015).

41. Sattler, M. Habitações de Baixo Custo Mais Sustentáveis: A Casa Alvorada e o Centro Experimental de Tecnologias Habitacionais Sustentáveis; Associação Nacional de Tecnologia do Ambiente Construído (ANTAC): Porto Alegre, Brazil, 2007; p. 488.

42. Cotterel, J.; Dadeby, A. The Passivhaus Handbook: A Practical Guide to Constructing and Retrofitting for Ultra-Low Energy Performance; Green Books: Devon, UK, 2012.

43. Ford, B.; Schiano-Phan, R.; Zhongcheng, D. The Passivhaus Standard in European Warm Climates: Design Guidelines for Comfortable Low Energy Homes. Part. 3: Comfort, Climate and Passive Strategies; Passive-On IEE Project: Nottingham, UK, 2013.

44. EDSL. EDSL TAS, 9.2.1.6; Environmental Design Solutions Limited (EDSL): Milton Keynes, UK, 2013.

45. INMETRO. Regulamento Técnico da Qualidade Para o Nível de Eficiência Energética Edificações Residenciais (RTQ-R). Portaria $n^{\circ} 18$ de 16 de Janeiro de 2012 [Technical Quality Regulation for the Level of Energy Efficiency in Residential Buildings (RTQ-R). Ordinance No. 18 of 16 January 2012]; Instituto Nacional de Metrologia, Qualidade e Tecnologia (INMETRO): Rio de Janeiro, Brazil, 2012.

46. INMETRO. Tabelas de Consumo de Energia/Eficiência Energética [Tables of Energy Consumption/Energy Efficiency]. Available online: http:/ / www.inmetro.gov.br/consumidor/tabelas.asp (accessed on 10 August 2020). 
47. PROCEL INFO. Equipamentos [Equipment]. Available online: http:/ /www.procelinfo.com.br/main.asp?View=\%7bE6BC2A5FE787-48AF-B485-439862B17000\%7d (accessed on 10 August 2020).

48. Morello, A. Avaliação do Comportamento Térmico do Protótipo Habitacional Alvorada; Federal University of Rio Grande do Sul (UFRGS): Porto Alegre, Brazil, 2005.

49. ASHRAE Guideline. ASHRAE Guideline 14-2002, Measurement of Energy and Demand Savings; American Society of Heating, Refrigerating and Air Conditioning Engineers (ASHRAE): Atlanta, GA, USA, 2002.

50. Schnieders, J.; Feist, W.; Schulz, T.; Krick, B.; Rongen, L.; Wirtz, R. Passive House for Different Climate Zones; Feist, W., Ed.; Passivhaus Institut and University of Innsbruck: Darmstadt, Germany, 2012.

51. Nicol, J.; Humphreys, M. Adaptive thermal comfort and sustainable thermal standard for buildings. Energy Build. 2002, 34 563-572. [CrossRef]

52. Nicol, F. Adaptive thermal comfort standards in the hot-humid tropics. Energy Build. 2004, 36, 628-637. [CrossRef]

53. ANSI/ASHRAE Standard 55. Thermal Environmental Conditions for Human Occupancy; American Society of Heating, Refrigerating and Air Conditioning Engineers (ASHRAE): Atlanta, GA, USA, 2010.

54. Nicol, J.; Humphreys, M.; Roaf, S. Adaptive Thermal Comfort: Principles and Practice; Routledge: Oxford, UK; New York, NY, USA, 2012.

55. Humphreys, M.; Rijal, H.; Nicol, J. Updating the adaptive relation between climate and comfort indoors; new insights and an extended database. Build. Environ. 2013, 63, 40-55. [CrossRef]

56. Rijal, H.; Humpreys, M.; Nicol, F. Adaptive thermal comfort in Japanese houses during the summer season: Behavioral adaptation and the effect of humidity. Buildings 2015, 5, 1037-1054. [CrossRef]

57. Givoni, B. Comfort, climate analysis and building design guidelines. Energy Build. 1992, 18, 11-23. [CrossRef]

58. Xavier, A. Predição de Conforto Térmico em Ambientes Internos com Atividades Sedentárias-Teoria Física Aliada a Estudos de Campo; Federal University of Santa Catarina (UFSC): Florianópolis, Brazil, 2000.

59. PINI. TCPOweb, May 2015 ed.; PINI: São Paulo, Brazil, 2015.

60. PINI. TCPO14 Edificações. Available online: http://loja.pini.com.br/pini/produto/TCPO14-Edificacoes.aspx (accessed on 17 June 2015).

61. Banco Central do Brasil. Dólar americano. Available online: https://www.bcb.gov.br/acessoinformacao/legado?url=https: $\% 2 \mathrm{~F} \% 2 \mathrm{Fwww} 4 . \mathrm{bcb}$. gov.br\%2Fpec\%2Ftaxas\%2Fbatch\%2Ftaxas.asp\%3Fid\%3Dtxdolar. (accessed on 10 July 2019).

62. ABNT. NBR 12721: Evaluation Criteria for Unit Costs and Elaborations of Contruction Budget for Incorporation of Joint Ownership Building-Procedure; Associação Brasileira de Normas Técnicas (ABNT): Rio de Janeiro, Brazil, 2006.

63. SINDUSCON-RS. CUB/RS do mês de Maio/2015-Residência Unifamiliar R1; Sindicato da Indústria da Construção Civil no Estado do Rio Grande do Sul (SINDUSCON-RS): Porto Alegre, Brazil, 2015.

64. SINDUSCON-RS. Evolução do CUB/RS NBR 12721/1999 em R\$ m²_Jan/1970-Mar./2009; Sindicato da Indústria da Construção Civil no Estado do Rio Grande do Sul (SINDUSCON-RS): Porto Alegre, Brazil, 2013.

65. CEAU. Módulo I: Remuneração do Projeto Arquitetônico de Edificações; Conselho de Arquitetura e Urbanismo do Brasil (CAU/BR): Brasília, Brazil, 2014.

66. CEAU. Módulo III-Remuneração de Execução de Obras e Outras Atividades; Conselho de Arquitetura e Urbanismo do Brasil (CAU/BR): Brasília, Brazil, 2014.

67. ABNT. NBR 15575-3: Residential Buildings_Performance_Part 3: Requirements for Floor Systems; Associação Brasileira de Normas Técnicas (ABNT): Rio de Janeiro, Brazil, 2013. 